\title{
CAPITALIZING OF THE GEOTOURISM POTENTIAL AND ITS IMPACT ON RELIEF. CASE STUDY: COZIA MASSIF, ROMANIA
}

\author{
Adriana Bianca OVREIU \\ University of Bucharest, Faculty of Geography, Department of Geomorphology, \\ Pedology and Geomatics, e-mail: ovreiuadrianabianca@yahoo.com \\ Iulian Andrei BĂRSOIANU* \\ University of Bucharest, Faculty of Geography, Department of Geomorphology, \\ Pedology and Geomatics, e-mail: andrei.barsoianu@gmail.com

\section{Laura COMĂNESCU} \\ University of Bucharest, Faculty of Geography, Department of Geomorphology, \\ Pedology and Geomatics, e-mail: lauracomanescu@yahoo.com \\ Alexandru NEDELEA \\ University of Bucharest, Faculty of Geography, Department of Geomorphology, \\ Pedology and Geomatics, e-mail: alexnedelea10@yahoo.com
}

Citation: Ovreiu, A.B., Bărsoianu, I.A., Comănescu, L., \& Nedelea A. (2019). CAPITALIZING OF THE GEOTOURISM POTENTIAL AND ITS IMPACT ON RELIEF. CASE STUDY: COZIA MASSIF, ROMANIA. GeoJournal of Tourism and Geosites, 24(1), 212-236. https://doi.org/10.30892/gtg.24117-354

\begin{abstract}
In the mountain area, the relief is the element of the geographical environment with the highest degree of tourist attractiveness, due to the variety and spectacularity of its forms and processes. The geotourism potential of the Cozia Massif is due to the evolution of the relief, conditioned by lithology, tectonics and climate. The cumulative action of these factors has led to the development of distinct landforms with a high favorability for geotourism activity: sharp edges and picks, impressive slopes, arcades, towers. In order to ensure the access of the tourists to the main areas of interest, a network of marked and unmarked tourist routes and trails has been identified, along with the forest roads. The present study has as main objective the analysis of the geotourism potential and infrastructure as well as highlighting the impact of tourism activities on the present-day morphodynamics. In this respect, the geotourism map of the Cozia Massif was drawn-up, representative profiles were made for each touristic route in order to characterize them in detail and to quantify the quantity of eroded material within the tourist routes, the hydric erosion being the main geomorphologic process intensified by the tourism activity.

The results of the study showed that the Cozia Massif has a high geotourism potential and the accessibility to the main geomorphositess is appropriate, being represented by a network of roads and paths with a total length of $162 \mathrm{~km}$. The tourist activities involve the increase of the anthropic pressure on the environment and the land
\end{abstract}

\footnotetext{
* Corresponding author
} 
degradation by increasing the erosion. The erosion processes are accelerated on the tourist trails along the slope, in the case of forest roads and exploitation roads affected in particular by logging, with a value of $41.15 \mathrm{t} / \mathrm{ha} / \mathrm{year}$.

Key words: geotourism, geotourism map, geomorphosites, tourist trails, degradation, erosion, Cozia Massif, Southern Carpathians, Romania

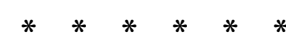

\section{INTRODUCTION}

The mountain regions have become increasingly vulnerable to changes imposed by human activities (Kucsicsa, 2013). Although the anthropic influence on the environment has been felt since ancient times, the man's morphogenetic role has been emphasized since the 20th century (Comănescu \&, Nedelea 2010), including in the mountain area.

This paper aims to evaluate the impact of tourism activities on the mountain environment, especially on the relief. Tourism can have positive effects for local communities, but at the same time it can be a stress factor for the environment (Kucsicsa, 2013) when the activities carried out are not efficiently and correctly managed. This context justifies the necessity of controlling the tourism exploitation of natural resources and the implementation of durable forms of tourism that minimize the human pressure on the mountain environment (Neches \& Erdeli, 2015). Concerns about this issue are numerous, with extensive literature that deals both theoretically and practically with the impact of tourism activities on the environment. Meinecke (1928) and Bates (1935) carried out the first studies about the ecological impact of mountain trips, following which, after 1960, an increased interest in this research direction would be given (Cole, 2004).

In the beginning of the 1970s, the concept of recreational ecology was implemented within a project of the Recreation Ecology Research Group (Gheorghe, 2009). Bayfield (1971, 1973, 1979) analyzes the effect of tourist activities on mountain regions in England and Scotland, applying the first methods of monitoring and restoring degraded spaces. A significant contribution in the field of ecological tourism, Liddle M. had through both individual (1997) and collaborative studies (Liddle \& GriegSmith, 1975; Liddle \& Kay, 1987). Frissell and Duncan (1965), emphasizes the idea that any type of tourism activity has negative effects on the natural space in which it is taking place. Ecology studies have also expanded spatially and temporarily, addressing new methods of analysis (Cole, 1978; Marion, Cole, 1996) and modeling of impact factors (Cole 1987, 1992), as well as new monitoring and management strategies (Cole, 1987, 1989, 2002; Hammitt \& Cole, 1998; Leung \& Marion, 2000; Marion \& Leung, 2001; Cater \& Cater, 2015; Cobbinah, 2015; Cobbinah et al., 2017; Khoshtaria \& Chachava, 2017). In Romania, the impact of tourism activities on the environment has not been the subject of numerous studies, being briefly dealt with in larger works. Most researches focused on ecological tourism in protected areas, such as Rodnei Mountains National Park, Retezat National Park, Bucegi Natural Park, and the areas in Făgăraş and Trascău Mountains (Gheorghe, 2009; Cocean, 2011; Kucsicsa, 2013).

Unlike ecological tourism that is exclusively carried out in protected natural areas (IUCN, 1996) and which can be defined as a "sustainable form of tourism that promotes conservation, has a low environmental impact and benefits local communities" (Fennel, 2003), the geotourism takes into consideration the landforms and the geological structures of a territory and can be practiced even in anthropically modified areas (Newsome \& Dowling, 2010). The term "geotourism" is relatively new, representing a form of sustainable tourism, based on the exploitation of the geological and 
geomorphological elements of an area (Stoffelen \& Vanneste, 2015). The first definition was given by Hose 1995, which considers geotourism to be a "way of promoting, preserving and understanding the geological heritage, the tourist going beyond the simple aesthetic appreciation of the landscape". Stueve et al. 2002 states that geotourism aims to "strengthen the distinctive geographic character of a place"", along with "preserving its natural and cultural heritage while also bringing benefits to the local population." Geotourism is a type of balanced tourism that aims at promoting geodiversity and preserving it by educating the tourist in the sense of awareness and appreciation of the geoheritage (Punmanee, 2008; Newsome \& Dowling, 2010; Dowling, 2013).

Therefore, geotourism exploits geosites and geomorphosites without creating imbalances in their level, aiming at preserving and protecting the environmental elements. On the other hand, the geotourism is also carried out for educational purposes, supporting the tourists' understanding of the functioning mechanism of the geographic environment and the awareness of the need to mitigate the human pressure put on it (Comănesu \& Nedelea, 2010; Yolal, 2012; Dowling, 2015; Necheș \& Erdeli, 2015).

For the practice of geotourism, the ways of transmitting geological and geomorphologic information to tourists is very important, in this regard the geotourism products, including the geotourism map, are essential. The geotourism map comprises the relief processes and forms, the geomorphological landscape, as well as the links established between the relief and the tourism activities (Comănescu et al., 2013). The purpose of this map is to promote the geoheritage of a territory, and to ensure the understanding of the scientific information and the tourists' awareness of the complexity of the landscape (Carton et al., 2005; Castaldini et al., 2005; Piacentini et al., 2011; Miccadei et al., 2013). Therefore, the geotourism map is an essential method of tourist information, presenting the main geosites and geomorphosites, the belvedere points, the tourist infrastructure, as well as an educational one, offering the possibility for the tourists to understand the processes and forms related to geology and relief, to be aware that the landscape is in a constant evolution, being the result of a set of internal and external factors (Bissig, 2008). The objective of the map is to highlight the value of the natural elements, their vulnerability, and the need to adopt conservation and protection measures (Miccadei et al., 2013). The first geotourism maps were made by researchers at the University of Modena for two complex geological and geomorphological regions of Italy (Abruzzo and Emilia Romagna) (Castaldini et al., 2008; 2009; 2011). In Romania, the specialists from the University of Oradea, who analyzed different spa resorts in Bihor County, showed interest in carrying out geotourism studies (Ilieș et al., 2011). At the University of Bucharest there have been developed studies that deal with mountain areas with high tourist potential, such as the Bucegi Mountains (Comănescu \& Nedelea 2012; Comănescu et al., 2013; Comănescu \& Nedelea, 2015).

The study area is a protected area in the II IUCN category- National Park and has a rich geomorphological heritage. In this context, the project aims to promote valuable geosites and geomorphosites with high tourist potential, as well to demonstrate the need to implement sustainable forms of tourism - geotourism.

\section{STUDY AREA}

The Cozia Massif is part of the Southern Carpathians, being a south-western subdivision of the Făgăraș Mountains. The Cozia National Park comprises almost the entire massif, but also the eastern part of the Căpăţânii Mountains and the DoabraCălineşti sector of the Lotrului Mountains. Its purpose is to „protect the floral, faunistic, hydrological, geological, geomorphological, palaeontological, speologic, pedological or other elements which are representative of the Carpathian area, while offering the 
possibility to make visits for scientific, educational, recreational and tourist purposes" (according to the Government Emergency Ordinance No. 57/2007 approved with amendments and completions by Law No. 49/2011, as subsequently amended and supplemented). The Cozia Massif is also included in two sites of community and avifaunistic importance, ROSCIO046 Cozia and ROSPA0025 Cozia-Buila Vânturariţa, which are part of the Natura 2000 network. The internal zoning of PN Cozia highlights three categories of areas: the full protection area- FPZ, the sustainable conservation area SCZ and the sustainable development area - SDZ (PN Cozia Management Plan, 2015).

The full protection area covers approximately half of the Cozia massif area (49.4\%) and contains the most valuable elements of the natural heritage. In this area can be identified the main geomorphosites: Cozia or Ciuha Mare Peak (1668 m), Stone Gate Archway, Bulzu Peak (1665 m), Durduc Peak or Crucea Ciobanului Peak (1568 m), Gardului Precipitous, Foarfecii Edge, Fruntea Oii Edge, Gardului Waterfall, Roșiei Stones, Şoimului Peak (1281 m), Vulturilor Stones. The durable conservation area is a buffer area located outside the full protection area. It occupies $34.73 \%$ of the study area and includes the geomorphosite Teofil's Tower. The Geomorphosites Traian's Table and Cozia Gorgesare included in the sustainable development area, which is $6.34 \%$ of the massif (Figure 1).

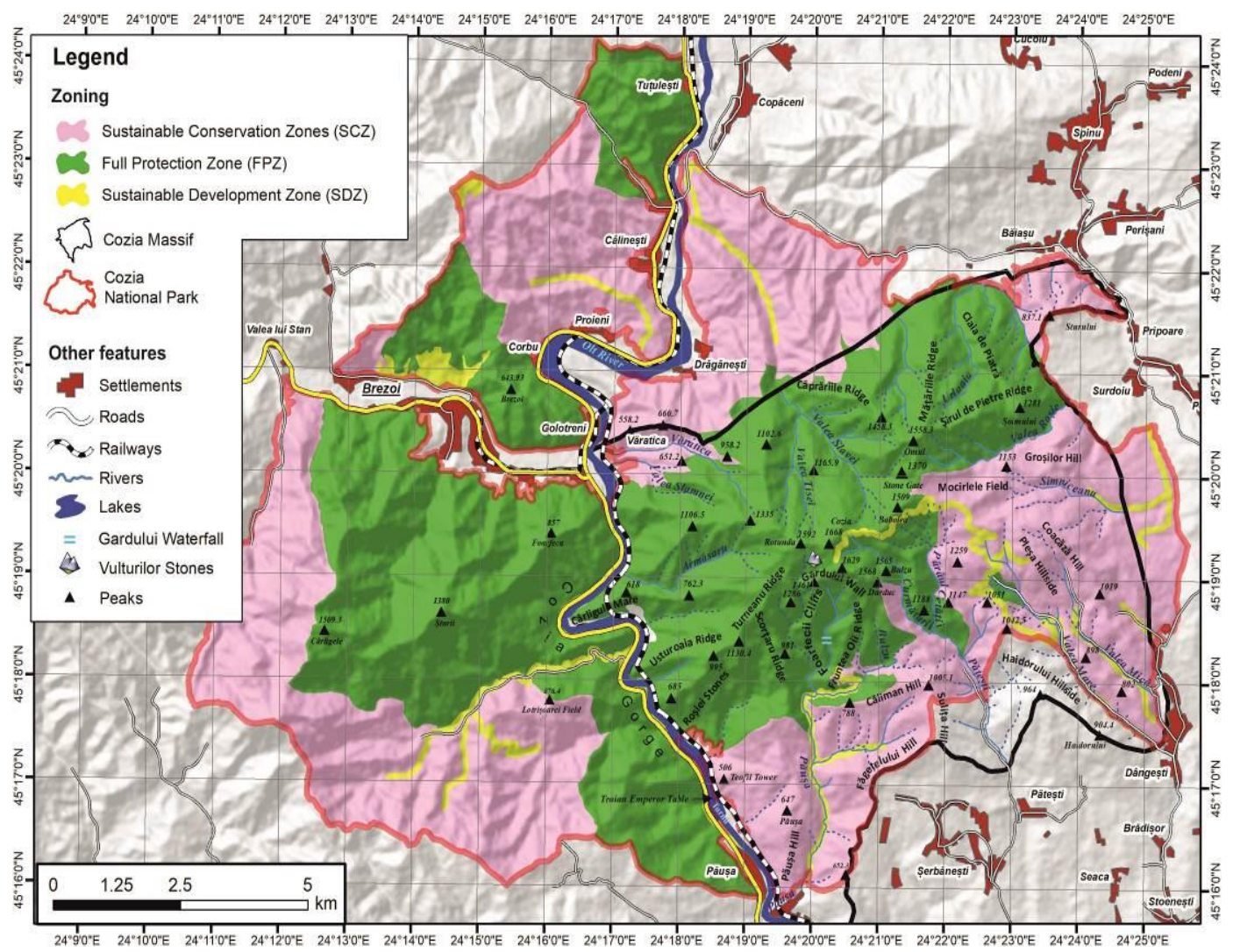

Figure 1. Zoning of National Cozia Park and 2000 Natura sites: ROSCIo046 Cozia and ROSPAo025 Cozia - Buila - Vânturarița

From the geological point of view, the Cozia Massif presents two main units: the central-northern one represented by the crystalline horst made up of gneiss (known as 
"Cozia gneiss") and paragnaise, and the southern one made up of the cretaceous and paleogenic sediment (sandstones, conglomerates, breccia, marl, sands) (Popescu \& Călin, 1987; Hann, 1990). The relief forms with the highest degree of tourist attractiveness are in the crystalline unity of Cozia, being the result of intense disaggregation, which was favored by the mineralogical composition of the augen gneiss, by the presence of the highly tectonized and cracked rocks and by the changing of climate over time. Thus, the tectonic, structural and climatic features have shaped the ruinous relief of the massif, where sharp peaks and sharp edges, slopes made of rocks, towers, stone gates, arches and caves can be identified. All of these, by their scientific value, are geomorphosites and have high tourist potential.

\section{METHODOLOGY}

In order to highlight the geotourism potential and the infrastructure in the Cozia Massif, a geotourism map was made, profiles were made along the tourist routes in order to characterize them in detail and the geodiversity index of the massif was calculated.

The geotourism map includes scientific information (geological and geomorphological), but especially tourist information (transport infrastructure, accommodation, belvedere points etc.). A first step in drawing-up the map is to create a database of information derived from different cartographic materials. Relief-related aspects (elevations, level curves, processes and relief forms, etc.) were obtained using the topographic map at 1: 25,000 scale and 1: 5,000 topographic plans. The lithological and tectonic elements were extracted from the geological map of Romania at a scale of 1 : 50,000 and the land coverage data were obtained from the orthophotoplans in 2012.

The tourist information were obtained both from the topographic and orthophotoplans materials, as well as from databases such as OSM (Open Street Map) and Google Maps. These data are also updated and supplemented with field information. The geomorphological and geological informations included in the geotourism map are presented in a simple and educational manner, being accessible to all categories of tourists and providing a good understanding of the landscape features. The tourist interest data refers to the total number of tourist routes and roads of different types that provide access to the tourist attractions, the places that are starting points for hiking, accommodation and shelter places (chalets and refuges), camps and stops, belvedere and tourist information points.

For the analysis of the infrastructure, the method of the profiles made along the tourist routes was used, with the purpose of highlighting the characteristics and the degree of their difficulty. The profiles provide information about morphometry (segment declivity, mean slope, level difference, total length of the route, total length of the climbing and descending sectors), land use, high risk sectors, total walking time and average time, link points with other routes and the belvedere points. Therefore, the profiles contain a large amount of information and offer the possibility of their qualitative correlation, being an optimal way of highlighting the relations between relief and tourism.

For the realisation of the profiles, the Global Mapper software was used, which processed the data derived from the numerical model of terrains obtained by vectorizing the level curves from the topographic map 1: 25,000, as well as the data recorded by a GPS device (Garmin 64st) during field trip. Subsequently, the profile was completed and finished in the Corel Draw graphics program. The geodiversity index was calculated based on all abiotic elements in the massif area using the following formula (Melelli 2017 with adaptations): $\mathrm{Gd}=\mathrm{Dg}+\mathrm{Dgm}+\mathrm{Dh}+\mathrm{Dp}+\mathrm{TRI}+\mathrm{TPI} / \mathrm{S}$, where Gd = geodiversity, $\mathrm{Dg}=$ geological diversity, $\mathrm{Dgm}=$ geomorphological diversity, $\mathrm{Dh}=$ hydrological diversity, $\mathrm{Dp}=$ pedological diversity, TRI = land roughness index, TPI = the index of the relief forms generated in DEM, (Melelli 2017 with adaptations) and $\mathrm{S}=$ 
area $\left(\mathrm{Km}^{2}\right)$. The assessment of the geodiversity involves determining the number of different physical elements per unit area. Thus, the Dissolve operation was performed to merge the vector geometry with the same attribute, then the Intersect function was used to split the vectors by the grid divided into $1 \mathrm{~km}^{2}$ areas. Subsequently, the centroid points were extracted for each element, using the Feature to Point function, and finally the sum of them was determined. To the total number of points in each $\mathrm{km}^{2}$ was added the average roughness index (TRI) obtained for each square of the grid by applying the ArcGis Zonal Statistic function. The impact of tourism activities on current morphodynamics has been assessed by quantifying the volume of eroded material on the surface of the roads and tourist routes of the massif using the USLE calculation formula (Ovreiu et al., 2018). In a first step, the amount of soil eroded in the whole area was estimated without taking into account the degree of compaction of the tourist paths favoring the occurrence of accelerated hydric erosion.

The USLE erosion pattern $(A=R * K * L S * C * P)$, where $A$ is the yearly eroded soil average, it is expressed in t.ha/year and includes parameters in the analysis that are related to: relief - length and slope (LS factor), soil - soil erodibility (K factor) (table 1) obtained according to texture of the soil types, climate - rain erosivity ( $\mathrm{R}$ factor) established according to Moţoc 1975, vegetation - land use (C factor) which recorded values depending on the classes of coverage, erosion control - measures to combat and limit soil degradation ( $\mathrm{P}$ factor), which in the present study received the value 1.

Table 1. Soil erosion factor (K) and vegetation coverage (C) - value classes

\begin{tabular}{|c|c|}
\hline \multicolumn{2}{|c|}{ K FACTOR } \\
\hline Soil type & Score \\
\hline Cambisols & 0.8 \\
\hline Spodosols & 0.9 \\
\hline Luvisols & 0.9 \\
\hline Alluvisols & 0.1 \\
\hline \multicolumn{2}{|c|}{ C FACTOR } \\
\hline Coverage clases & Score \\
\hline Forest & 0.2 \\
\hline Meadow & 0.3 \\
\hline Rockery & 0.02 \\
\hline
\end{tabular}

The second stage of the study determined the intensity of soil erosion along the tourist paths, taking into account the impact of mountain hiking on the soil cover, which differs according to the texture of the soil type. Soils with the silt texture have a low erosion potential compared to soils the texture of which is fine.

Therefore, the following erodibility classes have been established: clay-sandy cambisols - 0.9, clay-sandy clayey cambisoils -0.95, clay-argile cambisols- 1; clay-sandy spodsols - 1; clay-sandy luvisols - 1; alluvial soils - 0.2. Next step was to turn roads and paths into a polygon through the buffer operation, taking into account their importance. Subsequently, from the vector format, the transport infrastructure was converted into raster format, the pixel value ranging from 0.1 to 0.2 depending on the texture of the soil type. Pixels that do not correspond to roads and paths received the value o. Finally, the computation between the transport infrastructure and the erosion was achieved, resulting the soil erosion at the massif level, taking into account the impact of tourism activities. This result was intersected with the polyline transport network to calculate the length of the route segments with different erosion intensities.

The synthesis of the methodological approach includes information about the data sources needed for the study and presents the main data processing functions (Figure 2). 


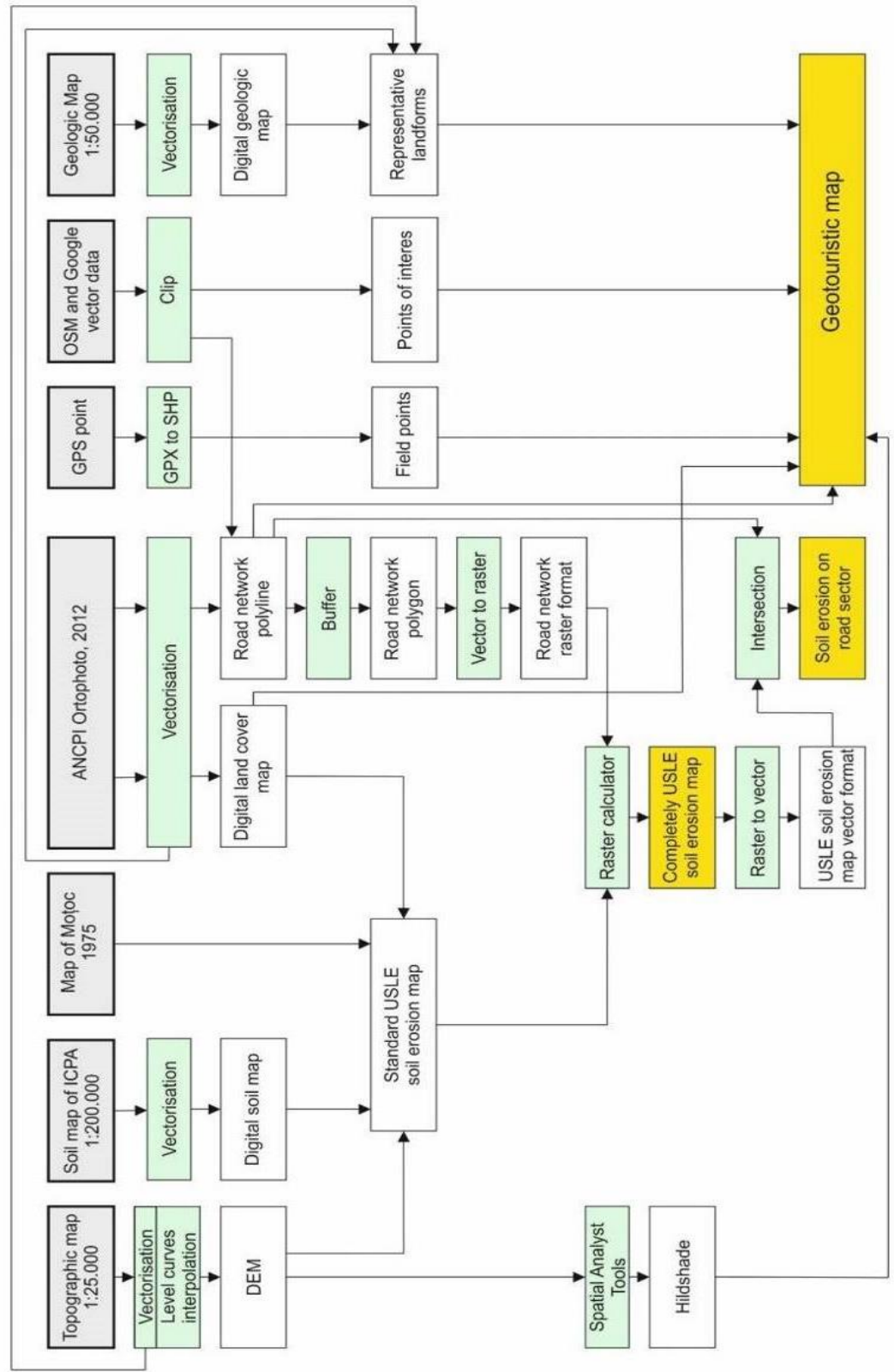

Figure 2. The methodological approach

\section{RESULTS}

The geotourism map of the massif (Figure 3) highlights the most attractive landforms from the tourist point of view, as well as the infrastructure that ensures their touristic capitalisation. The most important geomorphosites of the Cozia Massif are the ruinous relief forms, which were born due to intense disintegration of the augen gneiss and differential erosion. The presence of numerous faults and cracks in the Cozia crystalline "horst", as well as climatic conditions manifested in time, contributed to their 
shaping, giving them the appearance of towers, chimneys, arches, ledges, gutters, sharp edges, slopes made of rocks. The structure and tectonics of the massif also influenced the characteristics of the valleys, which have stepped profiles with thresholds on which waterfalls are formed. Thus, the main geomorphosites in the massif are: Stone Gate Archway, Foarfecii Cracks, Teofil's Tower, Vulturilor Stones, Roșiei Stones, Bulzului Cleft Rock, Gardului Precipitous, Fruntea Oii Edge, Cozia Peak, Durduc Peak, Traian's Table, Gardului Waterfall to which is added Cozia Gorges (Table 2, Figure 3).

Table 2. The marked tourist routes and acces roads of the Cozia Massif

\begin{tabular}{|c|c|c|c|c|c|c|c|c|}
\hline : & $\stackrel{n}{\vec{E}}$ & 岕 & 氛 & 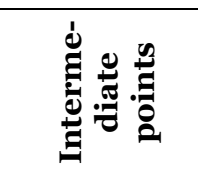 & ฮ & 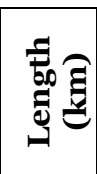 & 苞 & D \\
\hline 1 & & Păușa Village & $\begin{array}{l}\text { Cozia } \\
\text { Chalet }\end{array}$ & $\begin{array}{c}\text { Poiana } \\
\text { Stânișoarei }\end{array}$ & 1273 & 9,33 & $6 \mathrm{~h}$ & $\begin{array}{c}2,3,4 \\
9,10 \\
\end{array}$ \\
\hline 2 & & $\begin{array}{c}\text { Turnu Railway } \\
\text { Station }\end{array}$ & $\begin{array}{l}\text { Cozia } \\
\text { Chalet }\end{array}$ & $\begin{array}{l}\text { Turneanu } \\
\text { Sheepfold }\end{array}$ & 1263 & 7,54 & $5 \mathrm{~h} 3 \mathrm{O}^{\prime}$ & $\begin{array}{c}1,3,5 \\
7\end{array}$ \\
\hline 3 & & $\begin{array}{l}\text { Căciulata } \\
\text { Village }\end{array}$ & $\begin{array}{c}\text { Poiana } \\
\text { Stânișoarei }\end{array}$ & $\begin{array}{l}\text { Saddle La } \\
\text { Troiță }\end{array}$ & 420 & 3,86 & $2 h 30^{\prime}$ & $\begin{array}{c}1,2,9 \\
10,11 \\
\end{array}$ \\
\hline 4 & & Jiblea Village & $\begin{array}{l}\text { Cozia } \\
\text { Chalet }\end{array}$ & $\begin{array}{l}\text { Făgețelului } \\
\text { Interfluves, } \\
\text { Vlădesei Edge }\end{array}$ & 1293 & 10,36 & $7 \mathrm{~h}$ & 1 \\
\hline 5 & & $\begin{array}{c}\text { Lotru -Văratica } \\
\text { Railway station }\end{array}$ & \begin{tabular}{|c|} 
Cozia Peak - \\
Cozia Chalet
\end{tabular} & Urzicii Edge & 1368 & 8 & $5 \mathrm{~h} 3 \mathrm{O}^{\prime}$ & 2,7 \\
\hline 6 & & $\begin{array}{l}\text { Pripoare } \\
\text { Village }\end{array}$ & $\begin{array}{l}\text { Cozia } \\
\text { Chalet }\end{array}$ & Omul Peak & 1053 & 9,51 & $5 \mathrm{~h}$ & 8 \\
\hline 7 & & $\begin{array}{l}\text { Turnu Railway } \\
\text { Station }\end{array}$ & $\begin{array}{l}\text { Cozia } \\
\text { Chalet }\end{array}$ & $\begin{array}{l}\text { Roșiei } \\
\text { Stones }\end{array}$ & 1263 & 6 & $4 \mathrm{~h} 3 \mathrm{O}^{\prime}$ & 2,5 \\
\hline 8 & & Cozia Chalet & $\begin{array}{l}\text { Stone Gate } \\
\text { Archway }\end{array}$ & $\begin{array}{c}\text { Saddle } \\
\text { Mocirlele }\end{array}$ & 150 & & $2 \mathrm{~h}$ & 6 \\
\hline 9 & & $\begin{array}{c}\text { Poiana } \\
\text { Stânişoarei } \\
\end{array}$ & $\begin{array}{c}\text { Sălbaticul } \\
\text { Mountains }\end{array}$ & - & 50 & 0,85 & $1 \mathrm{~h}$ & $1,3,13$ \\
\hline 의 & & $\begin{array}{c}\text { Poiana } \\
\text { Stânișoarei }\end{array}$ & $\begin{array}{l}\text { Gardului } \\
\text { Waterfall }\end{array}$ & $\begin{array}{c}\text { Gardului } \\
\text { Valley }\end{array}$ & 200 & 0,53 & $1 \mathrm{~h}$ & $1,3,13$ \\
\hline$\Rightarrow$ & & $\begin{array}{l}\text { Poiana } \\
\text { Bivolari }\end{array}$ & $\begin{array}{c}\text { Turnu Railway } \\
\text { Station }\end{array}$ & $\begin{array}{l}\text { Teofil's } \\
\text { Tower }\end{array}$ & 190 & 1,72 & $1 \mathrm{~h} 3 \mathrm{O}^{\prime}$ & 3,2 \\
\hline$\approx$ & $\begin{array}{c}\text { Unmarked } \\
\text { path }\end{array}$ & $\begin{array}{l}\text { Surdoiu } \\
\text { Village }\end{array}$ & $\begin{array}{l}\text { Şoimului } \\
\text { Precipitous }\end{array}$ & $\begin{array}{l}\text { Roşiei } \\
\text { Gorges }\end{array}$ & 100 & 1,5 & $1 \mathrm{~h}$ & 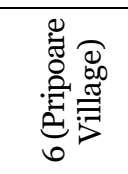 \\
\hline & $\begin{array}{l}\text { Unmarked } \\
\text { forest road }\end{array}$ & Păușa Village & $\begin{array}{c}\text { Poiana } \\
\text { Stânișoarei }\end{array}$ & Păușa Valley & 420 & 7 & $3 \mathrm{~h}$ & 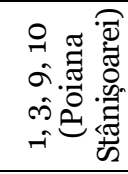 \\
\hline & $\begin{array}{c}\text { County } \\
\text { Road } 703 \mathrm{~N}\end{array}$ & $\begin{array}{l}\text { Dângești } \\
\text { Village }\end{array}$ & $\begin{array}{l}\text { Cozia } \\
\text { Chalet }\end{array}$ & $\begin{array}{c}\text { Plaiul } \\
\text { Mocirlele }\end{array}$ & 1073 & 14 & $\begin{array}{c}\text { accessible } \\
\text { to cars }\end{array}$ & 6,8 \\
\hline & $\begin{array}{l}\text { Unmarked } \\
\text { forest road }\end{array}$ & $\begin{array}{l}\text { Pătești } \\
\text { Village } \\
\end{array}$ & $\begin{array}{l}\text { Lacului } \\
\text { Stones }\end{array}$ & $\begin{array}{l}\text { Pătești } \\
\text { Valley }\end{array}$ & 240 & 2,5 & $1 \mathrm{~h} 3 \mathrm{O}^{\prime}$ & 4 \\
\hline
\end{tabular}




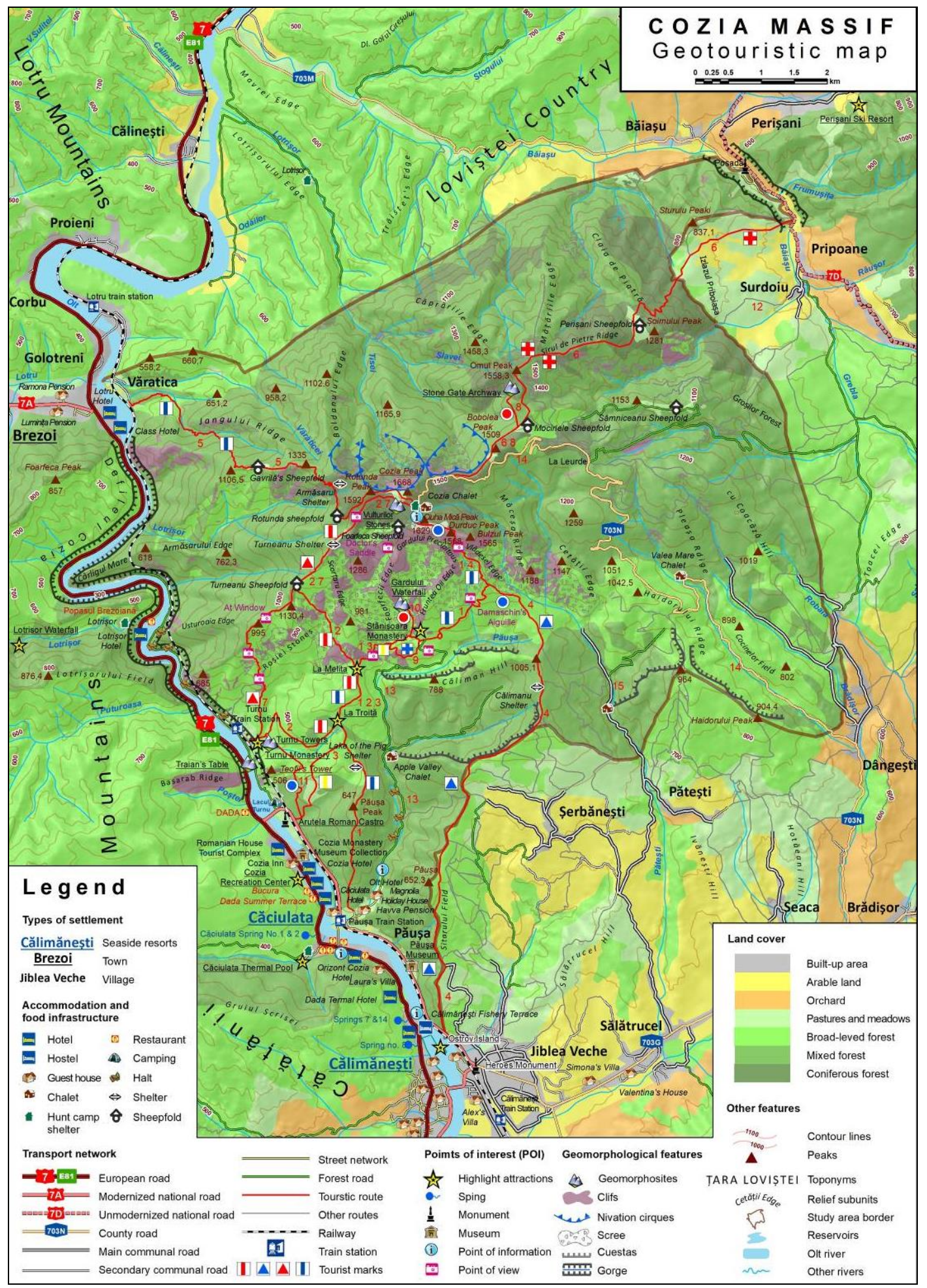

Figure 3. The geotourism map of Cozia Massif 
The Cozia or Ciuha Mare Peak has the highest altitude of the massif $(1668 \mathrm{~m})$ and represents the point from which the main peaks (Turneanu Edge, Vlădesei Edge, Rotunda Edge, Mocirlele Interfluves) are radially spread. This is the most important belvedere point, giving the possibility to observe, to the north, the slopes that delineate the valley of Tisa, further the crest of the Făgăraş Mountains, to the south, the Jiblea - Călimăneşti Depression and the Olt Valley, to the south-west, the impressive steep from the source of Seci Valley, to the west, the Cozia Gorges and the Buila - Vânturariţa Massif, and to the east, the Frunţi, Ghiţu, Iezer - Păpuşa massifs. The Durduc Peak, also called the Crucea Ciobanului, is a "rocky platform" situated at an altitude of $1568 \mathrm{~m}$ and is part of the southern steep of Cozia. It is an important belvedere point, offering a wide oppening to the source of Bulzului Valley and the Bulzu Peak (E), Scocul Ursului (S), Gardului Valley and Foarfecii Edge (V), Oltului Gorges and the Năruțu Mountain (SV). The Teofil's Tower is an erosion outlier at an altitude of $519 \mathrm{~m}$, situated in the west of the massif, near the anthropic lake of Turnu. It marks the boundary of Cozia Gorges, forming along with Mount Năruţu a tectonic alignment that makes the transition to the Subcarpathian region. Traian's Table is an extension of Teofil Edge in the Olt river bed, being individualized as a small island in the north of the Turnu lake. It presents important historical valences, being considered the stopping place of Emperor Traian's troops on their way to conquering Dacia. Foarfecii Edge are a sharp, rock-like, steep ridge that separates Seacă Valley from Gardului Valley. It is located in the central part of the massif, at an altitude of $1461 \mathrm{~m}$, and forms, along with the Durduc Peak, Bulzu Peak and Gardului Precipitous, the impressive southern steep of Cozia. Vulturilor Stones are located in the central part of the massif, near the Cozia Peak and represent a rocky steep in the form of "buttresses" which descends from Turneanu Edge and descends south-west to Seacă Valley. They are crossed by three tourist routes, the route 5 in the upper part and the routes 2 and 7 that overlap in the lower half of them and constitute a major belvedere point towards the Oltului Gorges. Roşiei Stones are peaks of rocks, abruptly located on the southern slope of Roşiei Edge. Gardului Precipitous are located in the central part of the massif, at the source of Gardului Valley, and represent a steep of about $500 \mathrm{~m}$, which together with Fruntea Oii Edge and Colții Foarfecii form the "Cozia stone fortress".

Fruntea Oii Edge is a sharp crest lying at an altitude of $1312 \mathrm{~m}$, with steep and rocky slopes descending to the Gardului Valley. Stone Gate Archway is about 1370m, on a narrow edge that heads westward from the Poarta de Piatră peak (1483 m). It looks like a gneiss arcade similar to the shape of taffons or as an open portal in the rock wall. Bulzului Cleft Rock is located in the central part of the massif, at an altitude of $1560 \mathrm{~m}$, in the north of Vlădesei edge, delimiting the springs of the Curmăturii Valley and the Bulz. It is a tower-like peak with steep slopes, on which the disintegration of the gneiss has formed true "stone faces". Together with Ciuha Mare, Ciuha Mică and Durduc Peak forms the central crest of Cozia. Gardului Waterfall is located on the river of the same name, at an altitude of $745 \mathrm{~m}$. It has developed on a 20-meter high threshold, which marks the maximum narrowing point of the Gardului Valley, and presents vertical slopes made of rock, that belong to the edges of Foarfecii Edge and Fruntea Oii Edge.

Cozia Gorges is a narrow valley, with steep slopes, situated between the Căpățânii Mountains to the east and the Cozia Massif to the west, over a $16 \mathrm{~km}$ length. The anthropic interventions for the development of the transport infrastructure have caused the instability of the slopes, which are strongly affected by rock-fall, but also the design and implementation of specific structural works (the location of protection nets, concrete and stone walls, gabbions). The tourist infrastructure is presented on the geotourism map (Figure 3) includes the transport routes that provide the access of the tourists inside the massif, the accommodation units and the shelters. The Cozia Massif benefits from a transport network with a length of approximately $200 \mathrm{~km}$, of which $55.8 \mathrm{~km}$ are the 
surrounding roads and railways that provide access for tourists to the localities at the base of the massif. Thus, we can exemplify the European road E81, which connects, through Olt Gorges, between the Extra-Carpathian and Intra-Carpathian regions and the national road $7 \mathrm{~A}$, which is the belt road of Călimănești, both crossing the western side of the massif. These are added the $703 \mathrm{M}$ county road that enters along the Băiaşu valley in the north of the study area, the non-modernized road $7 \mathrm{D}$ from the $\mathrm{NE}$ to the massif connecting the villages Perişani - Pripoare - Surdoiu, county roads $703 \mathrm{G}$ and $703 \mathrm{~N}$ connecting the localities Jiblea Veche and Dângeşti, in the south of the massif and the forest road between the localities Surdoiu and Dângești, on its eastern side, which closes the ring road network surrounding the Cozia Massif. The railway transport is represented by the 201 highway which follows the western slope of Cozia and connects with the main tourist routes of the massif (routes 1, 2, 3, 4, 5, 7, 11) (Table 2).

The transport infrastructure inside the massif is represented by marked and unmarked forest roads and tourist paths, which presents a concentric unfolding, starting from the access points situated at the base of the massif towards the central part of it, where Cozia Chalet is located $(1573 \mathrm{~m})$. The most important access route for tourists to the altitude of $1600 \mathrm{~m}$ is the county road $703 \mathrm{~N}$ (route 14), which was initially arranged as a forest road. It starts from Dângeşti, along the Valea Mare River, it is accessible all year round and connects with routes 6 and 8. Other forest roads that allow access by car to certain tourist attractions or which connect with important tourist routes are: the forest road on the Păuşa Valley (route 13) which reaches the Stânişoara Monastery, and from here you can go on hiking routes 1 and 4 towards the chalet and the Cozia Peak, on route 9 to the Singuraticul Peak or Route 10 to the Gardului Waterfall; the forest road on the Sâmniceanu valley crossing the Cozia road (the county road $703 \mathrm{~N}$ ) near Plaiul Mocirlele, at the point called "La Leurde". This forest road, although impractical for cars, provides a relatively easy accessibility to the center of the massif. The most used hiking trails are the marked tourist trails, which are found along the main valleys or the interfluvial peaks, most of them starting from Olt Gorges, on the western side of the massif. An exception is the route 6 which has the starting point near the village of Pripoane, located at the NE of the massif. The marked paths are the most frequented because they allow access to the main geomorphosites, which justifies the need to inform the tourists about their degree of difficulty, but also about other elements of interest.

The Government Decision no. 77/2003 includes the tourist routes that require a walking time of 4-8 hours and a sustained physical effort on certain sectors in the category of medium difficulty routes, and those with a difference in the level between $500-1500 \mathrm{~m}$ are included in the high difficulty category. Therefore, the difficulty of the tourist trails should be determined on the basis of all route parameters and not only from the topographic parameters. In this regard, two representative routes were chosen for analysis, the route 2 departing from the Turnu Monastery (most frequented by tourists) and the route 5 starting from Văratica, both going towards Cozia Chalet and Cozia Peak (Table 2, Figure 3). The touristic route number 2 (Figure 4) is marked with red lane and runs predominantly on the western slope of the Cozia Massif, along Trăznita Edge, then crosses the cliffs of Scorţaru Edge, and finally follows Turneanu Edge to the Cozia Chalet. This itinerary presents many elements of geotourism interest: the rocky scraps of Scorţaru Edge and the Vulturilor Stones Geomorphosite; the relief forms shaped in cretaceous sandstone and the contact between the sedimentary rocks and the Cozia gneiss which can be seen on the right side of the route immediately after "La Meliță"Saddle, areas covered by scree detached from the steep slopes of Muchia Scorţaru; the springs at the origin of the Turnu River that are necessary for the water supply of the tourists; the protected endemic species, such as the Cozia rosehip; the belvedere points and the connection with other tourist routes. 
Route no. 2: Turnu - "La Meliță" - Turneanu Sheepfold - Cozia Chalet

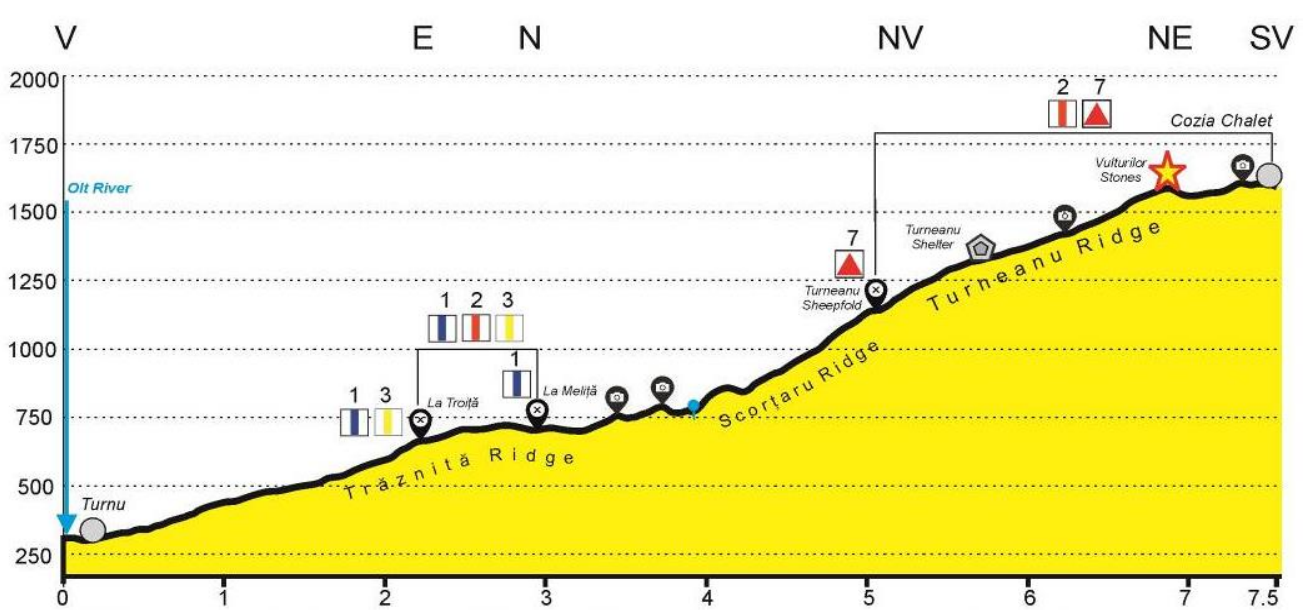

\begin{tabular}{|c|c|c|c|c|c|c|c|c|}
\hline \multicolumn{9}{|c|}{ A } \\
\hline & & & & & & & & \\
\hline \multirow{2}{*}{\multicolumn{2}{|c|}{1 hour }} & & & & & & & \\
\hline & & \multicolumn{3}{|c|}{$2^{1 / 2}$ hours } & & \multicolumn{3}{|c|}{2 hours } \\
\hline \multicolumn{3}{|c|}{ Accessible all year round } & \multicolumn{6}{|c|}{ Recommended during summer } \\
\hline $\begin{array}{c}\text { Route } \\
\text { parameters }\end{array}$ & $\begin{array}{l}\text { Climbing } \\
\text { sectors }\end{array}$ & Flat sectors & $\begin{array}{l}\text { Descent } \\
\text { sectors }\end{array}$ & $\begin{array}{c}\text { Level } \\
\text { difference }\end{array}$ & $\begin{array}{c}\text { Average } \\
\text { slope }\end{array}$ & $\begin{array}{l}\text { Maximum } \\
\text { slope }\end{array}$ & $\begin{array}{l}\text { Minimum } \\
\text { slope }\end{array}$ & $\begin{array}{c}\text { Total } \\
\text { walking } \\
\text { time }\end{array}$ \\
\hline Value & $5820 \mathrm{~m}$ & $1020 \mathrm{~m}$ & $720 \mathrm{~m}$ & $1263 \mathrm{~m}$ & $12^{\circ}$ & $45^{\circ}$ & $0^{\circ}$ & $5.5 \mathrm{~h}$ \\
\hline Percentage & $76.98 \%$ & $13.5 \%$ & $9.52 \%$ & & & & & \\
\hline
\end{tabular}

\section{L e g e n d}
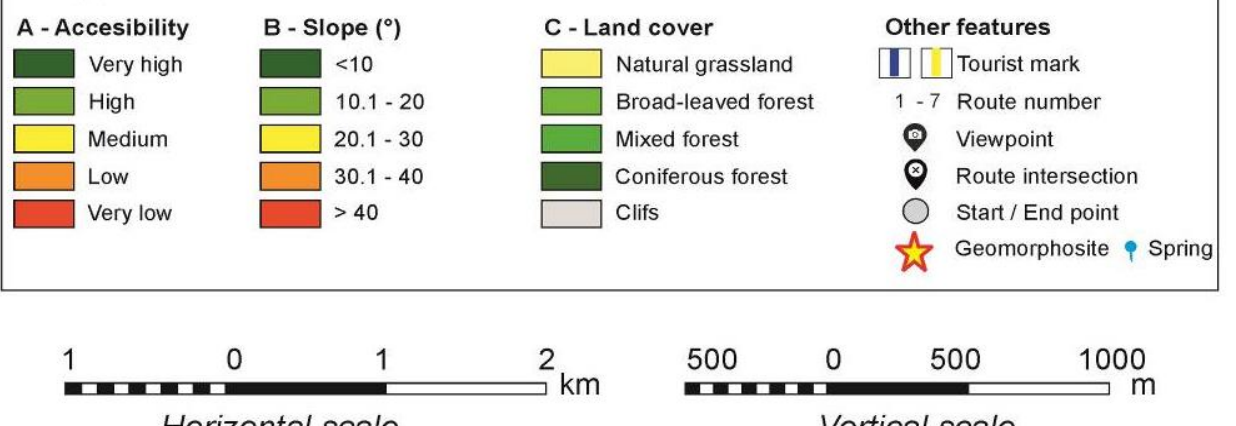

Horizontal scale

Vertical scale

Figure 4. The profile of touristic route 2 (Turnu Monastery - Cozia Chalet)

A first belvedere point is situated in the proximity of "La Meliţă" Saddle, where the Păuşa Valley and the Foarfecii Edge, the Ciuha Mică, Durduc and Bulzu peaks can be observed. Scorţaru Edge offers the opportunity to observe the Olt Gorges, the slopes and the rock peaks of Roşiei Edge and the "Rocky battresses of Roşii Stones" (Popescu \& Călin, 1987). Turneanu Edge is an important point of view to the slopes of Scorţaru Edge from the Turnu Valley, to the Olt Gorges, but it offers the possibility of observing the 
Cozia massif as a whole. Therefore, it is possible to highlight the "Cozia rock fortress" consisting of the Durduc, slopes, the Vulturilor Stones, the Foarfecii Edge, the Ciuha Mică Peak and the steep slopes of Valea Seacă. Also, from this point we can see the the Cozia Peak. An interesting perspective on the massif and the surrounding area also is also offered by the belvedere point situated in the proximity of the chalet, from where you can see Poiana Stânişoara, Pauşa Valley, the Olt Gorges, Jiblea-Călimăneşti Depression and Buila-Vânturariţa Massif. From the point of view of the topographic accessibility, the touristic route 2 presents medium accessibility on $57.08 \%$ of the length and reduced accessibility on $\mathbf{1 7 . 5 2 \%}$ of the length. The sectors with high and very high accessibility represent $15.60 \%$ and $8.33 \%$ respectively of the total length. Very low accessibility was recorded for $1.47 \%$ of the route. Hardly accessible sectors overlap with the high slopes areas, rocks and scree of the Trăsnită Edge, Scorţaru Edge and Vulturilor Stones. The sector with the highest degree of accessibility difficulty is located in the last part of the route, where the trail crosses more rocky slopes and rocks and a narrow opening of a "horn" on the left side of the route. According to the topographic accessibility, route 2 presents a medium level of difficulty, but also taking into account the Government Decision no. $77 / 2003$, it can be said that it presents a medium to high degree of difficulty.

The touristic route number 5 (Figure 5) is marked with blue strip and first follows the left slope of the Slamnei valley, parallel to Gruiul Jangului Edge, then climbs along the Urzicii Edge, crosses the Rotunda Hill and continues towards the Cozia peak (1668 m). This route impresses by the rocks sector of the Urzica Edge called "țurțudane" (Popescu \& Călin, 1987). These are isolated peaks that rise above the sharp Urzica Edge. The route also allows for the observation of the rocky slopes of the Jang, the rocky slopes of the Slamna Valley, the gnais slopes at the origin of the Armăsarul Valley, the slopes of the Slamna Valley detached from the Jang precipitous, and the slopes of the most important geomorphosite of the massif, the Cozia peak. The itinerary offers numerous points of view on the main forms of relief of the massif, as well as interesting perspectives on the neighbouring geographic area. The belvedere point near Urzica Sheepfold makes it possible to observe the Armăsarul hill that descends to the Olt's Big Meander, the Olt Gorges, the Lotru Mountains and the western hills of the Făgăraş Mountains. The narrow edge of Urzica, with many sharp peaks, offers great landscapes towards the heights of the Buila-Vânturariţa, Căpăţânii and Lotru Mountains, but also to the Claia cu Brazi peak (1525 m). In the valley between the Rotunda (1593 m) and Cozia $(1668 \mathrm{~m})$ peaks there is a a rock peak which is a belvedere point towards the Tisa River and the Loviştea Depression (in the northern part), but also to the central part of the massif, where we have the landscape of Foarfecii Edge (towards the south).

The steep and deforested slope of the Cozia Peak is the most important point of the massif, which offers large perspectives on the mountainous area. Route 5 shows a medium accessibility on $42.18 \%$ of the total length, high accessibility and very high accessibility on $30.76 \%$ and on $10.01 \%$ respectively, and low accessibility and very low on $16.58 \%$ and $0.47 \%$ respectively. A first sector that requires sustained physical effort and presents a high level of difficulty in terms of topographical accessibility is the left slope of the Slamnei Valley, running parallel to Gruiu Jangului Edge, where the tourist trail crosses a narrow interfluvial space, with rocks and then it climbs the very steep northeastern slope of the massif, detached from Depresiunea Loviştea through the Brezoi Fault. Portions of the route with very low accessibility have been identified on the sharp slope of Urzica in the space of the ("țurțudanele Urzicii") steep and rocky peaks.

Also, sectors crossing structural thresholds of the rock edges have a very high degree of difficulty, making it advisable to bypass them at the base of the slopes when weather conditions are not favourable. These areas can be identified in the upper basin of 
the Armăsarul Valley, on the slopes of Rotundă Edge, which climbs to the tip of the same name, on the heavily inclined slopes of the Cozia Peak. According to the topographic accessibility and the time required for the route, it falls within the category of mediumdifficulty touristic routes. However, the high level difference and the sectors with very high risk of injury (structural thresholds, sharp edges, rocky slopes), which require adequate training and equipment, determine its inclusion in the high-difficulty routes class.

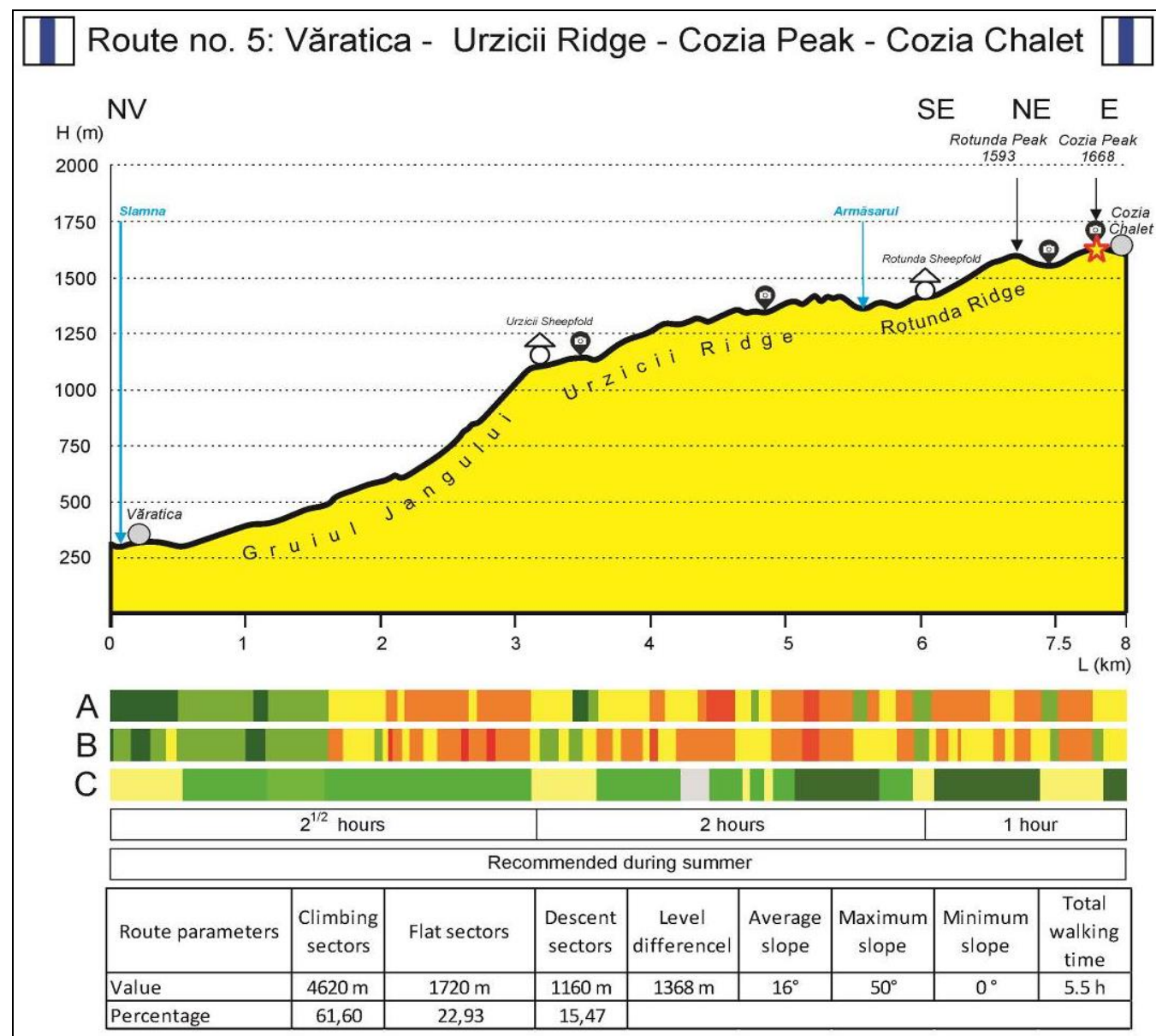

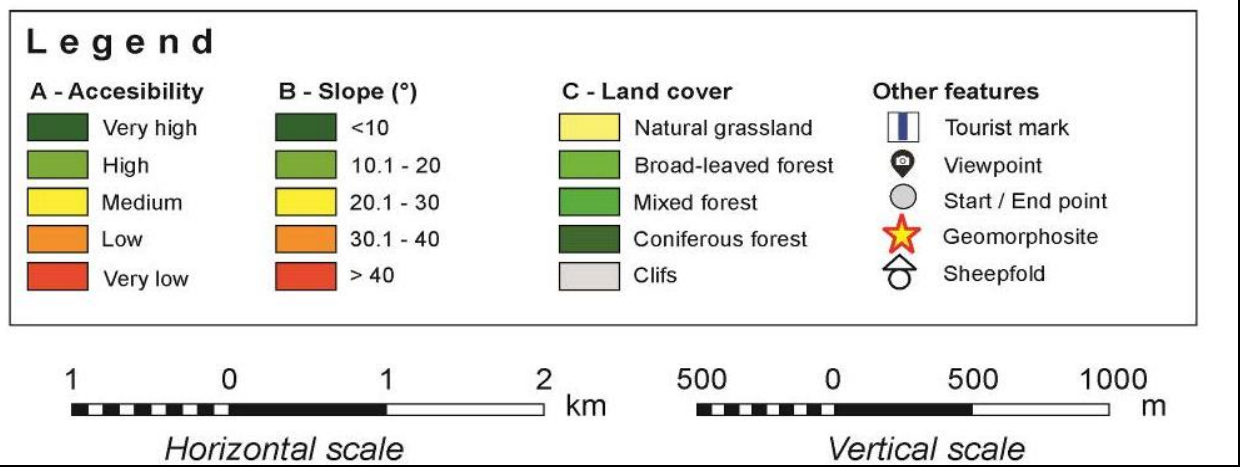

Figure 5. The profile of touristic route 5 (Văratica - Cozia Chalet) 
Another aspect that came to our attention was the identification of the most accessible areas of the massif, based on the density of the roads and paths. The highest values of the transport infrastructure density $\left(>5 \mathrm{~km} / \mathrm{km}^{2}\right)$ were recorded for $5.51 \%$ of the area and include the eastern part of the massif. This area presents topographical conditions which are favourable to the access ways (hilly relief with low slopes, low energy and fragmentation), where the county road $704 \mathrm{~N}$, the Sâmniceanu forest road and a large number of unmarked paths can be identified. Areas with high density values $(4-5 \mathrm{~km} /$ $\mathrm{km}^{2}$, namely $3.68 \%$ ) can also be seen in the western part of the massif, the Olt Valley being the starting point for most of the tourist trails (2, 7 - the Turnu depressionary basin; 3-11 - Poiana Bivolari to the south of Teofil's Tower), to which are added the national road $7 \mathrm{~A}$, the thoroughfare 201 and the Turnu - Cârligul Mare forest road. At the opposite end, there is the northern, very steep and hardly accessible slope of the Cozia Massif, which has density values below $1 \mathrm{~km} / \mathrm{km}$ (33.71\%). The central high part of the massif is the point of convergence of the tourist trails, but due to the very high relief and rock steepness, the density of the trails is reduced, ranging from 1-2 km/ km² (29.15\%) (Figure 6).

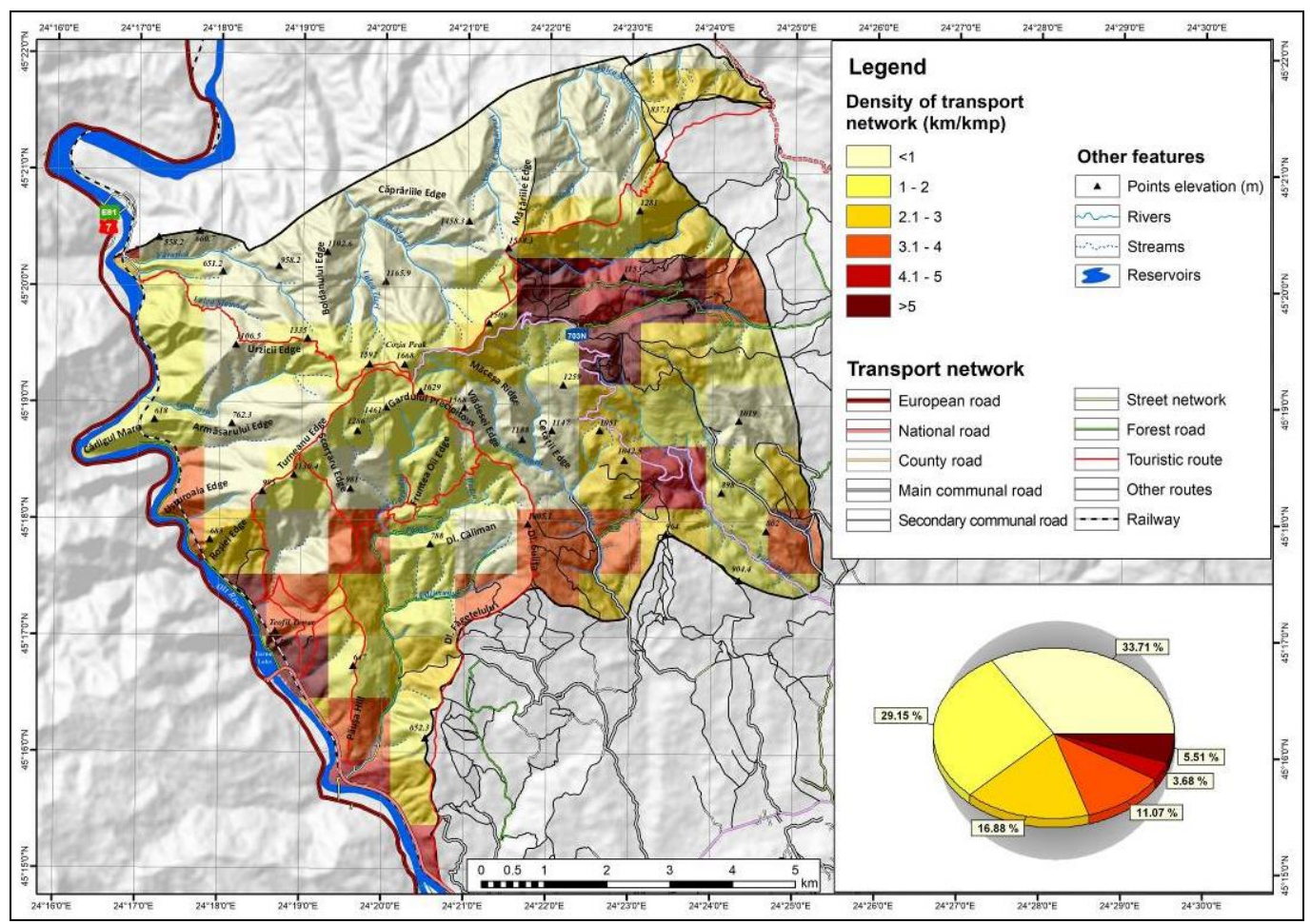

Figure 6. The density of transport network

The accommodation infrastructure is very developed in the resorts at the base of the massif (Călimăneşti, Căciulata), where tourists benefit from accommodation in hotels, hostels, campsites and food and recreational facilities. In the central part of the massif there is only one chalet (the Cozia chalet), which is also the intersection point of most tourist routes $(1,2,4,5,6,7,14)$. It is situated at $1573 \mathrm{~m}$ altitude, in the extended valley between the Cozia (1668 m) and Ciuha Mică (1629 m) peaks. In the proximity, there is the Cozia forest canton. The chalet can be reached in maximum 6 hours on all the abovementioned tourist routes, but also on the county road $703 \mathrm{~N}$ which allows access by car. 
From here you can go for short hikes of about 2 hours, to the main geomorphosites of the massif: the Cozia Peak on route 5, the Durduc Peak and Bulzului Cleft Rock on route 1, Vulturilor Stones on route 2, Stone Gate Archway on routes 6 and 8, the Omu Peak on the route 6 . Towards the the massif's outskirts there are the Valea Mărului chalets on Păuşa Valley (trail 13) and Valea Mare (route 14). Also, the massif has other shelters such as: Turneanu Shelter and Sheepfold (trails 2, 7), Armăsarul Shelter, Gavrilă Sheepfold and Rotunda Sheepfold (trail 5), Lacul Porcului Shelter (trail 1), Călimanu Shelter (trail 4), Mocirlele and Perișani Sheepfold (trail 6).

The high geotourism potential of the Cozia Massif is highlighted by the value of the geodiversity index that records high values (30-35) for $30.27 \%$ of the massive area. The high geodiversity is predominantly located in the central sector of the studied area with a varied relief with specific landforms. Very high values $(35.01-40)$ of the geodiversity were obtained for only $2.55 \%$ of the area and characterize the sectors with varied lithological composition (5-7 different types of rocks), intensely strongly fissured (2.80 $\mathrm{km} / \mathrm{km}^{2}$ and $1.61 \mathrm{~km} / \mathrm{km}^{2}$ respectively), with complex geomorphology (7-8 different types of relief and geomorphological processes), highly fragmented $\left(6.14 \mathrm{~km} / \mathrm{km}^{2}\right.$ and 5.34 $\mathrm{km} / \mathrm{km}^{2}$ respectively) with varied pedology (3 different soil types) and high TRI (4.16) and TPI (8-10) indices (Figure 7).

In this context, the suitable management of the tourism activities in order to limit the anthropic pressure on the environment and the degradation of the land by surface erosion processes has become a necessity. Soil compaction due to tourism activities reduces its capacity to allow infiltration and storage of precipitation water, creating conditions which are favourable to the emergence of the accelerated water erosion. The results of the USLE analysis show the increase in the amount of eroded soil in accordance with the development of tourism activities. Although the differences are insignificant at the level of the entire study area (Figure 8), for the tourist trails the quantity of materials removed exceed the soil recovery rate, thus showing an intense erosion and a strong degradation of the tourist trails. Of the total of $2119.07 \mathrm{t} / \mathrm{ha} / \mathrm{yr}$, $41.15 \mathrm{t} / \mathrm{ha} /$ year are eroded from the transport infrastructure of the massif. Intensive erosion processes occupy $0.91 \%$ of the total surface of the roads and trails, namely 1.69 ha, removing 1.01 tonnes of material annually (Table 3, 4).

\section{DISCUSSION}

The north-central part of the Cozia Massif has the highest geotourism potential due to the ruinous relief imposing the landscape and which impresses with massive and high-energy relief. This sector is located at an altitude of over 1,00o meters and overlaps with the Cozia augen gneiss, which, through disaggregation, gave rise to specific forms of relief, such as rock, horns, arches, edges and sharp rocky edges. The radial orientation of the interfluves and valleys has also imposed the direction of the tourist trails, which converge to the central part of the massif, where the Cozia peak and the Cozia Chalet are located. For example: Turneanu Edge (trail 7), Trăznită EdgeScorțaru Edge (trail 2), Vlădesei Edge - Sitarului Interfluves (trail 4), Gruiul Jangului Urzica Edge (trail 5), Șirul de Pietre Interfluves- Mocirlele Interfluves (trail 6). The massif can be crossed in the SV-NE direction, combining routes 1, 2, 4 or 7 with route number 6 , but also in the general N-S direction following trail 5 , then trail 4. This type of hiking requires a stop at Cozia Chalet. Therefore, we cannot talk about a main ridge route, and it's necessary to achieve an itinerary that includes the main geomorphosites in the high sector of Cozia. We propose a route that includes the Cozia Peaks, Vulturilor Stones, Gardului Precipitous, Durduc Peak, Bulzului Rock Cleft, which offer numerous belvedere points to Foarfecii Edge, Fruntea Oii Edge and Cozia Gorges. This trail can be 
Adriana Bianca OVREIU, Iulian Andrei BĂRSOIANU, Laura COMĂNESCU, Alexandru NEDELEA

dedicated to tourists who once arrived at the Cozia Chalet by car, they want to take a short 1-2 hour hike to the most important objectives of the massif. New tourist trails can also be opened in less accessible areas (Foarfecii Edge, Seacă Valley, Bulzului Valley and the origin of the Tisa River) for tourists who do not have a special training.

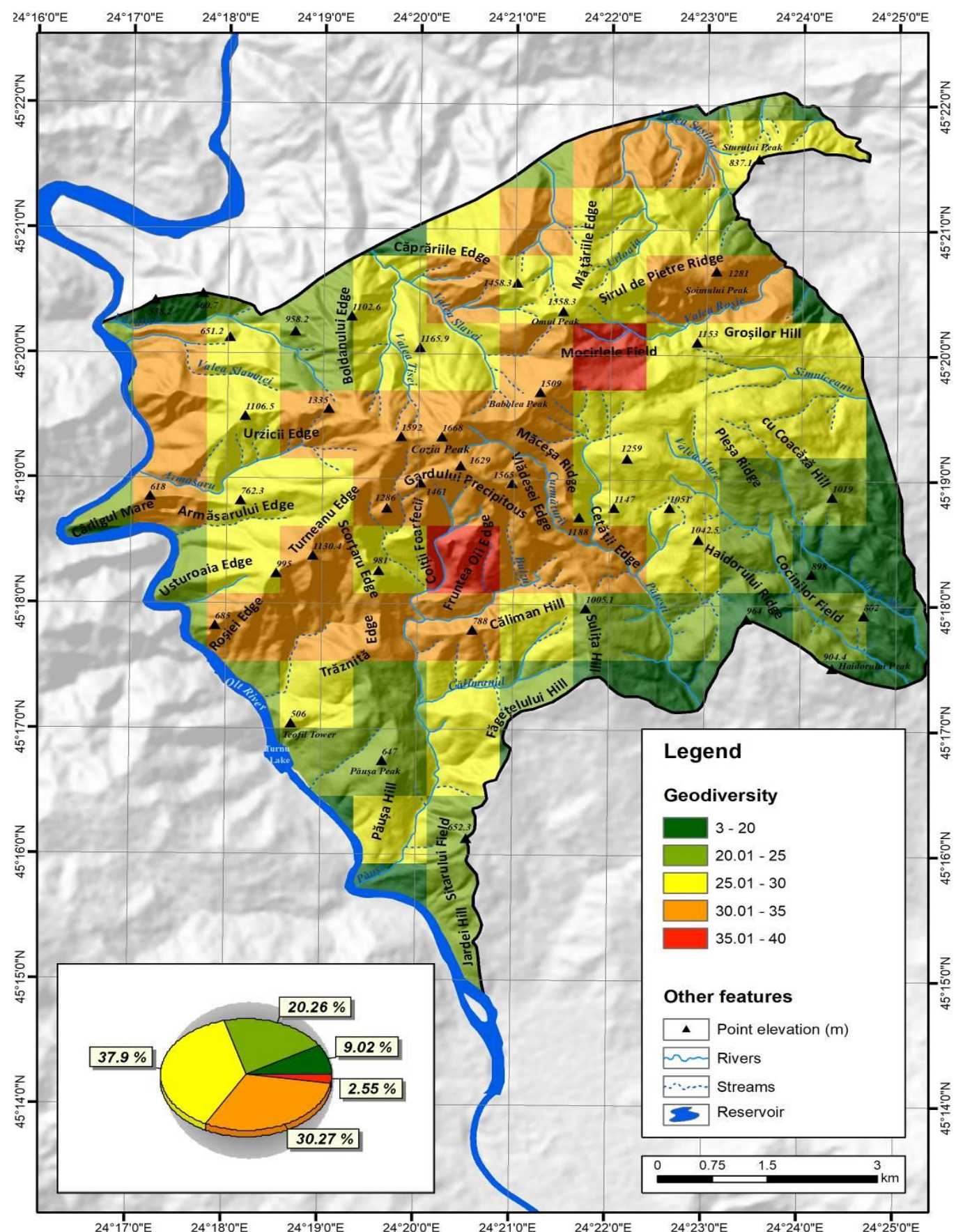

Figure 7. The geodiversity index 
Capitalizing of the Geotourism Potential and Its Impact on Relief. Case study: Cozia Massif, Romania

Table 2. The total yearly amount of eroded soil using USLE (Cozia Massif)

\begin{tabular}{|c|c|c|c|}
\hline USLE (t.ha/yr) & Surface (ha) & Total (t/yr) & Percentage \\
\hline$<0.1$ & 1217.38 & 121.74 & 15.63 \\
\hline $0.1-0.2$ & 2169.52 & 433.90 & 27.85 \\
\hline $0.2-0.3$ & 2534.77 & 760.43 & 32.53 \\
\hline $0.3-0.4$ & 1428.27 & 571.31 & 18.33 \\
\hline $0.4-0.5$ & 329.46 & 164.73 & 4.23 \\
\hline $0.5-1.1$ & 111.61 & 66.97 & 1.43 \\
\hline Total & 7791.01 & 2119.07 & 100 \\
\hline
\end{tabular}

Table 3. The total yearly amount of eroded soil using USLE (roads and touristic routes)

\begin{tabular}{|c|c|c|c|}
\hline USLE (t.ha/yr) & Surface (ha) & Total (t/yr) & Percentage \\
\hline$<0.1$ & 57.46 & 5.75 & 30.86 \\
\hline $0.1-0.2$ & 63.36 & 12.67 & 34.03 \\
\hline $0.2-0.3$ & 42.09 & 12.63 & 22.61 \\
\hline $0.3-0.4$ & 16.94 & 6.78 & 9.10 \\
\hline $0.4-0.5$ & 4.63 & 2.32 & 2.49 \\
\hline $0.5-1.1$ & 1.69 & 1.01 & 0.91 \\
\hline Total & 186.17 & 41.15 & 100 \\
\hline
\end{tabular}

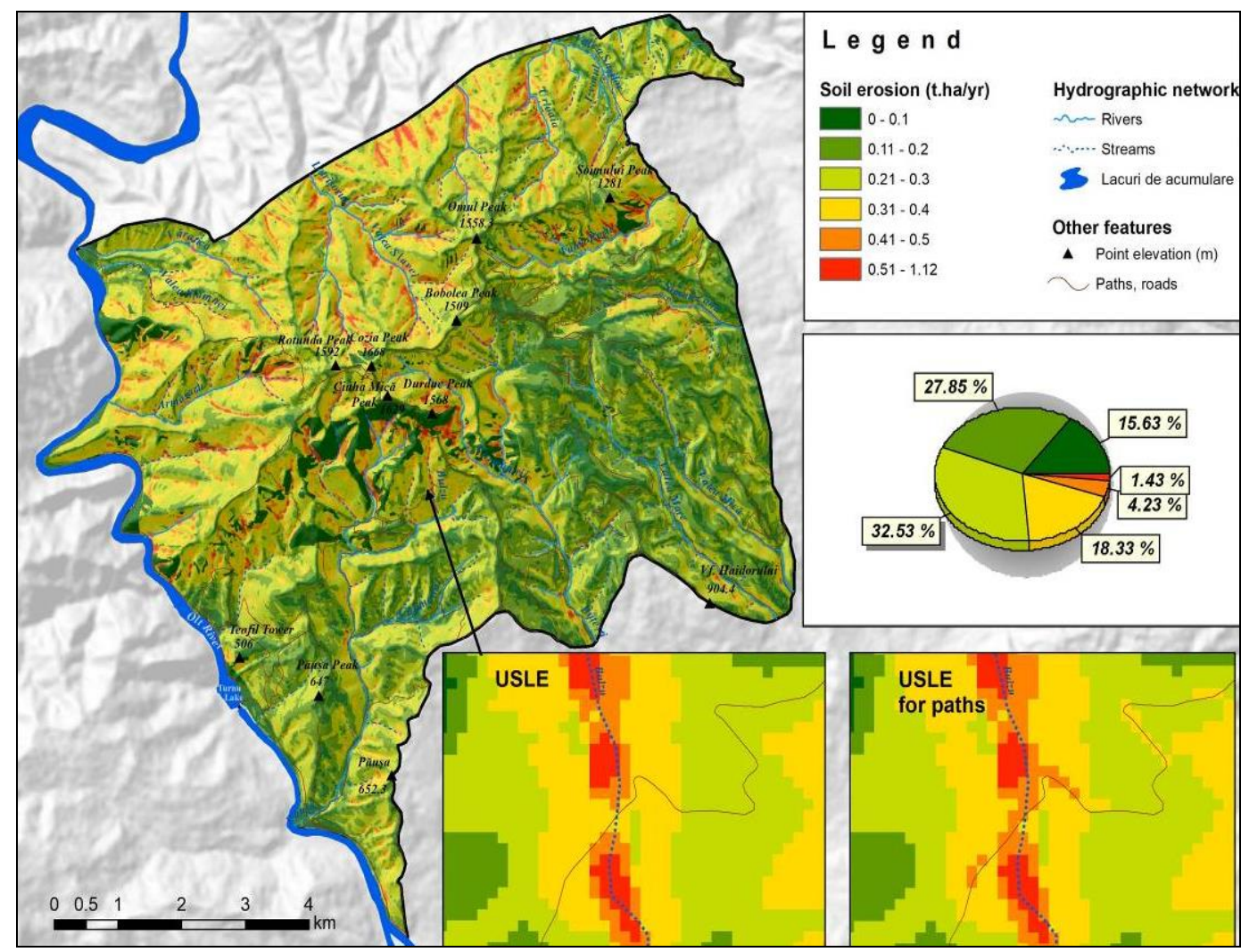

Figure 8. Soil erosion in Cozia Massif

The exploitation of the geotourism potential of the Cozia Massif must be carried out in accordance with the legal acts regarding the protected areas, in order to prevent 
and limit the negative consequences on the environment. Practicing pedestrian or motorized tourism where the transport infrastructure allows access to cars, motorcycles or ATVs has negative effects on all the components of the environment, but especially on the soil and the vegetal cover. In some sectors, the impact of tourism activities is amplified by the transport of logs for the forest exploitation, which can destroy the paths or degrade the access roads. The tourist activities, regardless of their type, have a negative impact on the environment, and it is necessary to set acceptable impact thresholds. The intensity of the impact varies according to the type of use, the profile of the tourists, the characteristics of the environmental elements, the quality of the tourist facilities, the measures for prevention, control and improving the impact and depending on the season of use (Cole, 1981, 1987). The season in which the substrate is used for tourism purposes is an important factor because it can lead to a significant increase in the impact on the soil. In the rainy season or with moisture input from snow melting, it is over-saturated and becomes more vulnerable to degradation.

The topographic conditions in which the tourist routes are developed are important for the manifestation of the impact, so that the trails that are framed along the slope and not along the level curve favor the water channeling and the occurence of accelerated erosion. In this context, the most affected are the fine-textured soils with low organic horizons and those that are poorly drained (Bayfield, 1973). The value of the correlation coefficient " $R$ " (0.43) demonstrates the relationship established between the intensity of soil erosion and the relief energy (Figure 9).

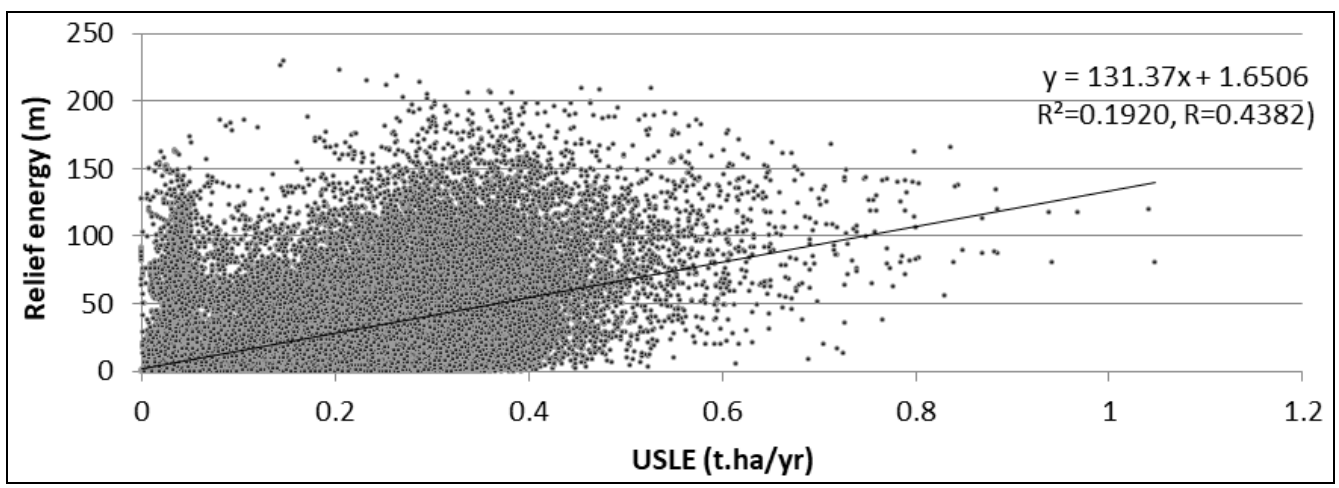

Figure 9. The correlation between the intensity of soil erosion to the trails and relief energy

In figure 10 it can be observed that high erosion values are recorded on the trails crossing the central part of the massif, with high relief energy, but also the steep northern slope of Cozia. Large quantities of material are also eroded annually in the eastern part of the massif where there is a high density of forest and exploitation roads. The main tourist activity with consequences on the environment is the treading of the soil and vegetation by the tourists. This results in the uprooting and removal of the plants and hence the reduction of soil coverage with vegetation; the displacement of particles from the upper organic horizons of the soil; compaction and treading of the soil. Mountain pedestrian tourism degrades tourist paths by removing and transporting material particles from the soil's organic horizon protecting the lower horizons, or by reducing the resistance of the soil particles, making them easier to be detached and transported by erosive agents such as flowing water. The impact of hiking on the soil and vegetation can be major at local level (tourist trails, belvedere points, stopping spaces and camping sites) and reduced on a large scale (if we relate to the entire mountain massif). This is evidenced by the soil erosion 
values obtained using the USLE formula, which demonstrates a higher erosion along the pathways, but an insignificant increase at the level of the whole study area (Figure 8).

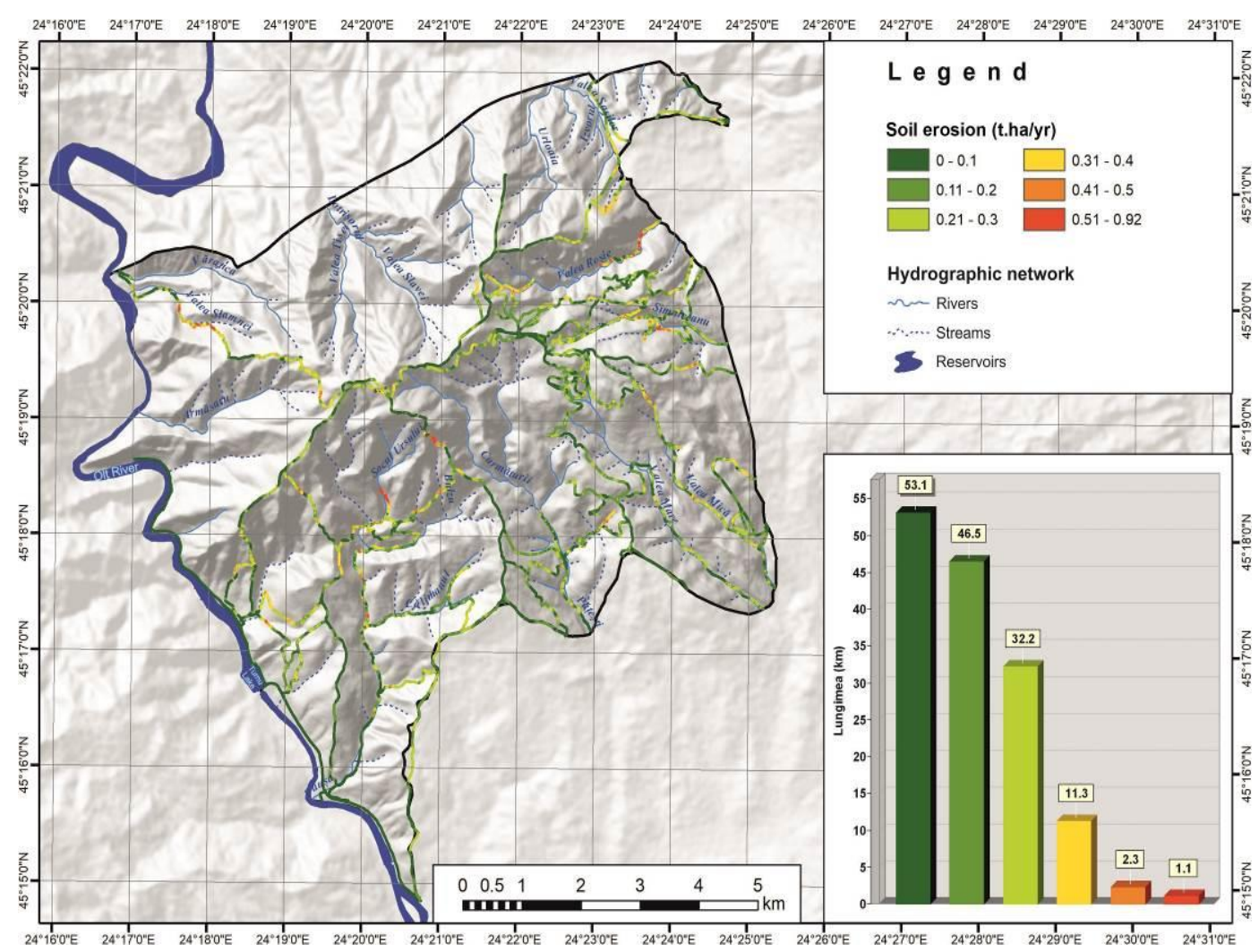

Figure 10. The soil erosion calculated at the infrastructure level

The effect of hiking on the level of tourist routes evolves rapidly, sectors that are poorly designed or maintained, and are substantially damaged (Fish et al., 1981; Cole, 1991). The accelerated hydric erosion along the tourist routes causes their degradation by the appearance of rills and ravines (Figure 11). As paths erode and become impracticable, secondary pathways develop, parallel to the initial route, which leads to the expansion of the soil degradation process by compaction (Figure 11). Practicing hiking outside the routes system increases their impact on soil and vegetation. For suitable management and monitoring of the impact of tourism activities on soil and relief, it is necessary to have an approach that takes into account that the degradation of the elements of the natural environment is the cumulative effect of several categories of factors and not just of the pedestrian tourism: pluvial erosion, the execution and maintenance of the routes (slopes cutting, the revealing the roots of the trees, the emergence of the drainage ditches), plus the hiking.

\section{CONCLUSIONS}

The Cozia Massif has a rich and varied geoheritage that supports the implementation of geotourism activities. Promoting the geotourism potential is dependent on tourists' source of information on its value. Another objective of geotourism activities is to preserve and protect the elements of the geographic environment. The tourism activities carried out in the mountain area can have negative consequences on the relief by increasing the 
morphodynamic potential and activating present- day geomorphological processes, but also at the level of the soil, vegetation and fauna. The degradation of the tourist routes through accelerated erosion, as a result of rainwater sewage along the paths, is one of the most important problems faced by the Cozia Massif. In this context, it is necessary to develop sustainable paths that do not exceed the environmental support capacity and ensure minimal impact on it. Geotourism is also an important tool for a sustainable development and promotion of the environment, able to create opportunities to generate revenue for the community, thus contributing to the improvement of the local economy. Information and training of tourists in the sense of awareness regarding the importance and vulnerability of the environmental elements is another function of this type of tourism.
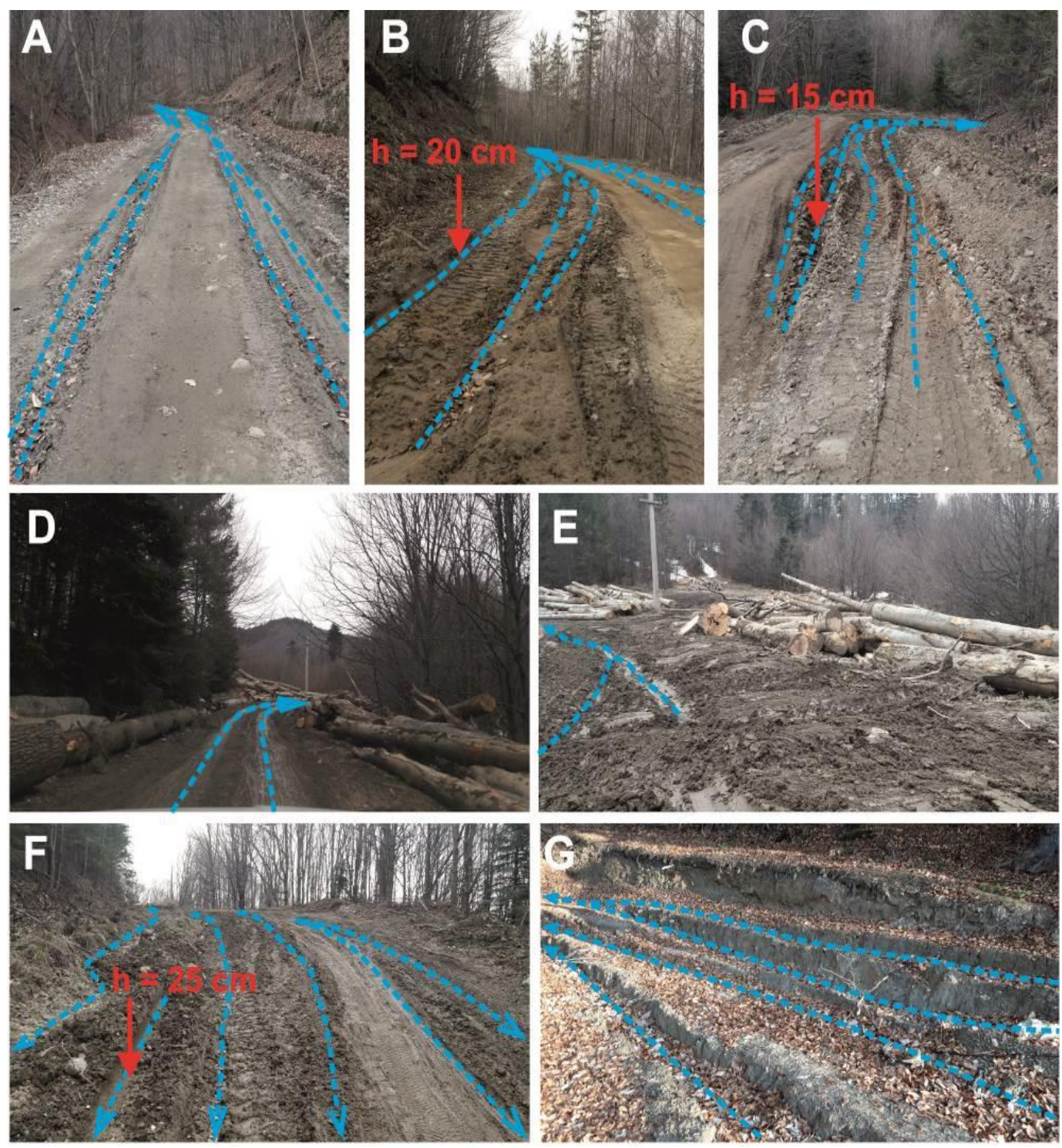

Figure 11. The degradation of the transport infrastructure through erosion processes: A, B, C, D, E, F - route 14 (703 N); G - logging route on Valea Mare (crosses route 14); 

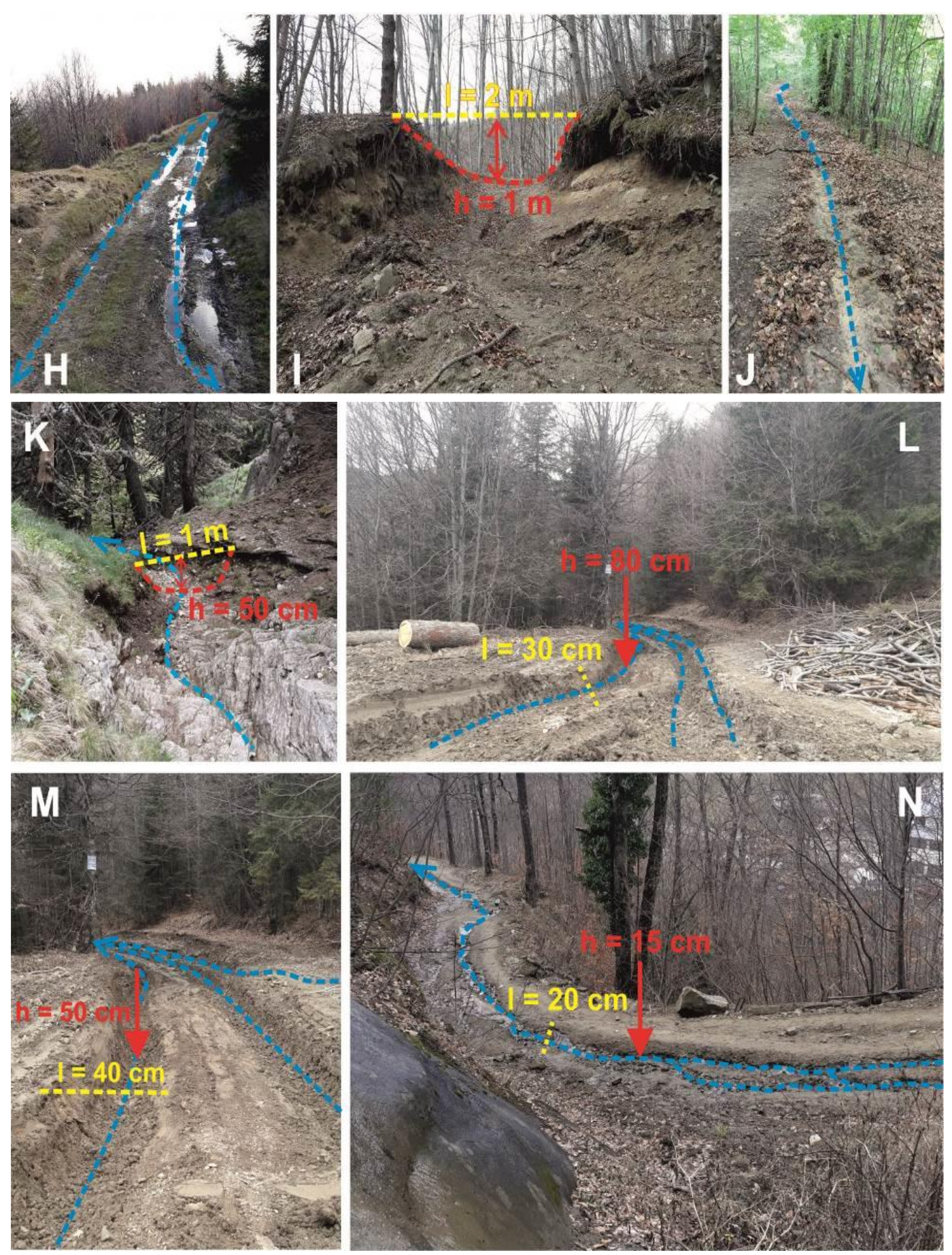

Figure 11. The degradation of the transport infrastructure through erosion processes:

H - tourist route 14 "Plaiul Mocirlele"; I - exploitation road on Păuşa Valley (crosses route 13); $\mathrm{J}$ - tourist route $7, \mathrm{~K}$ - tourist route 1,$4 ; \mathrm{L}, \mathrm{M}$ - logging route on Mare Valley (crosses route 14); $\mathrm{N}$ - touristic route 2 

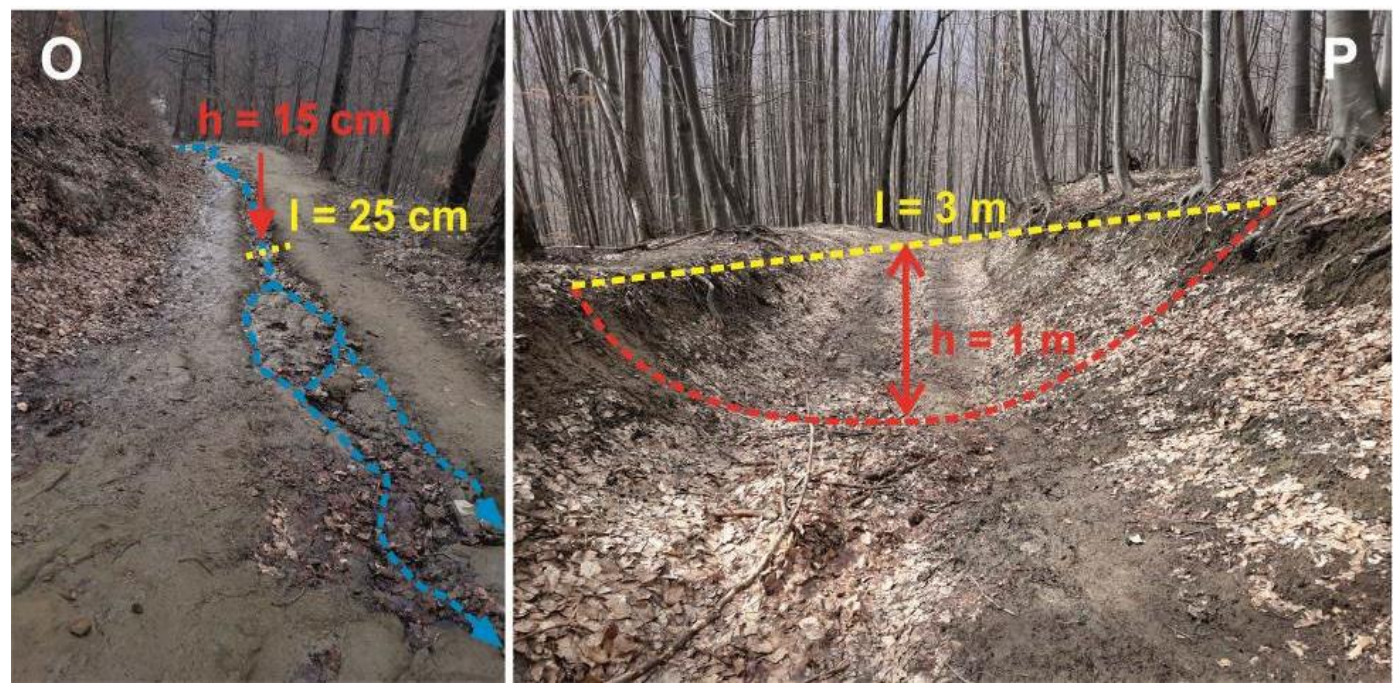

Figure 11. The degradation of the transport infrastructure through erosion processes: $\mathrm{O}, \mathrm{P}$ - touristic route 2

\section{REFERENCES}

Alessa, L. \& Earnhart, C., G. (2000). Effects of soil compaction on root and root hair morphology: implications for campsite rehabilitation. In: Cole, D.N., McCool, S.F., Borrie, W.T., and O’Loughlin, J. (comps.) Wilderness Science in a Time of Change Conference. Vol. 5. Wilderness Ecosystems, Threats and Management. Proceedings RMRS-P-15-VOL-5. U.S. Department of Agriculture, Forest Service, Rocky Mountain Research Station, Ogden, Utah, pp. 99-104.

Bates, G., H. (1935). Vegetation of footpaths, sidewalks, cart-tracks, and gateways. Journal of Ecology, 23, 470-487.

Bayfield, N., G. (1971). Some effects of walking and skiing on vegetation at Cairngorm. In: Duffey, E. and Watt, A.S. (ed.) The Scientific Management of Plant and Animal Communities for Conservation. Blackwell, Oxford, 469-485.

Bayfield, N., G. (1973). Use and deterioration of some Scottish hill paths. Journal of Applied Ecology,10, 639-648.

Bayfield, N., G. (1979). Recovery of four montane heath communities on Cairngorm, Scotland, from disturbance by trampling. Biological Conservation 15, 165-179.

Bissig, G. (2008). Mapping geomorphosites: an analysis of geotourist maps, Geoturystika, 3(14), 3-12.

Carton, A., Coratza, P., \& Marchetti, M. (2005). Guidelines for geomorphological sites mapping: examples from Italy, Géomorphologie: relief, processus, environnement, 3, 209-218.

Castaldini, D., Conventi, M., Coratza, P., Dallai, D., Liberatoscioli, E., Sala, L., \& Buldrini, F. (2011). Touristenvironmental map of the Regional Natural Reserve of the Salse di Nirano, Municipality of Fiorano Modenese, (Carta Turistico-Ambientale della Riserva Naturale Regionale delle Salse di Nirano, Comune di Fiorano Modenese), Tipolitografia Notizie, Modena.

Castaldini, D., Coratza, P., Bartoli, L., Dallai, D., Del, Prete, C., Dobre, R., Panizza, M., Piacentini, D., Sala, L.,\& Zucchi, E. (2008). Environmental Tourist Map of Monte Cimone, Park of Frignano (Carta Turistico Ambientale del Monte Cimone, Parco del Frignano), Eliofototecnica Barbieri, Parma.

Castaldini, D., Valdati, J., \& Ilies, Dorina, Camelia (2009). Geomorphological and Geotourist Maps of the Upper Tagliole Valley (Modena Apennines, Northern Italy) (Carta geomorfologica e geo-turistica dell'alta Valle delle Tagliole (Appennino Modenese, Italia settentrionale)), Mem. Descr. Carta Geol. d'It.LXXXVII, 29-38.

Castaldini, D., Valdati, J., \& Ilieş, Dorina, Camelia (2005). The contribution of geomorphological mapping to environmental tourism in protected areas: examples from the Apennines of Modena (Northern Italy), Revista de Geomorfologie, 7, 91-106.

Cater, C., \& Cater, E. (2015). Ecotourism, International Encyclopedia of the Social \& Behavioral Sciences (Second Edition), 105-109.

Cobbinah, P., B. (2015). Contextualising the meaning of ecotourism, Tourism Management Perspectives 16, 179-189.

Cobbinah, P., B., Amenuvor, D., Black, R., \& Peprah, C. (2017). Ecotourism in the Kakum Conservation Area, Ghana: Local politics, practice and outcome, Journal of Outdoor Recreation and Tourism, http://dx.doi.org/10.1016/j.jort.2017.09.003. 
Cocean, G. (2011). Inventory Cards For Regionally Relevant Geomorphosites, Romanian Review of Regional Studies, Vol VII, No1, Cluj Napoca.

Cole, D., N. (1978). Estimating the susceptibility of wildland vegetation to trailside alteration. Journal of Applied Ecology, 15, 281-286.

Cole, D., N. (1981). Managing ecological impacts at wilderness campsites: an evaluation of techniques. Journal of Forestry, 79, 86-89.

Cole, D., N. (1987). Research on soil and vegetation in wilderness: a state-of-knowledge review. In: Lucas, R.C. (comp) Proceedings-National Wilderness Research Conference: Issues, State-of-knowledge, Future Directions. General Technical Report INT-220. U.S. Department of Agriculture, Forest Service, Intermountain Research Station, Ogden, Utah, pp 135-177.

Cole, D., N. (1989). Low-impact recreational practices for wilderness and backcountry. General Technical Report INT-265. U.S. Department of Agriculture, Forest Service, Intermountain Research Station, Ogden, Utah, $131 \mathrm{pp}$.

Cole, D., N. (1991). Changes on trails in the Selway-Bitterroot Wilderness, Montana, 1978-89. Research Paper INT450. U.S. Department of Agriculture, Forest Service, Intermountain Research Station, Ogden, Utah, 5 pp.

Cole, D., N. (1992). Modeling wilderness campsites: factors that influence amount of impact. Environmental Management 16, 255-264.

Cole, D., N. (2002). Ecological impacts of wilderness recreation and their management. In: Hendee, J.P. and Dawson, C.P. Wilderness Management: Stewardship and Protection of Resources and Values. Fulcrum Publishing, Golden, Colorado, pp. 413-459.

Cole, D., N. (2004). Impacts of hiking and camping on soils and vegetation: a review. In: Buckley, R. (Ed.), Environmental Impacts of Ecotourism. CABI Publishing, New York, pp. 41-6o.

Comănescu, L., \& Nedelea, A. (2010). Analysis of some representative geomorphosites in the Bucegi Mountains: between scientific evaluation and tourist perception. Area 4, 406-416.

Comănescu, L., \& Nedelea, A. (2012). The assessment of geodiversity - a premise for declaring the geopark Buzăului County (Romania), J. Earth Syst. Sci. 121, 6, 1493-1500.0124.

Comănescu, L., \& Nedelea, A. (2015). Public perception of the hazards affecting geomorphological heritagecase study: the central area of Bucegi Mts. (Southern Carpathians, Romania), Environmental Earth Sciences, 73, 12, 8487-8497.

Comănescu, L., Nedelea, A., \& Dobre, R. (2013). The geotouristic map - between theory and practical use. Case study - the Central Sector of the Bucegi Mountains (Romania), GeoJournal of Tourism and Geosites, Year VI, no. 1, vol. 11, 16-22.

Dowling, R., K. (2013). Global Geotourism - an emerging form of sustainable tourism. Czech J. Tour. 2 (2), 59-79.

Dowling, R., K. (2015). Geotourism. In: Cater, C., Garrod, B., Low, T. (Eds.), The Encyclopedia of Sustainable Tourism. CABI, Oxford, 231-232.

Fennel, D. (2003). Ecotourism, Routledge, New York.

Fish, E., B., Brothers, G., L., \& Lewis, R., B. (1981). Erosional impacts of trails in Guadalupe Mountains National Park. Landscape Planning 8, 387-398.

Frissell, S., S., \& Duncan, D., P. (1965). Campsite preference and deterioration in the Quetico-Superior canoe country. Journal of Forestry 65, 256-260.

Gheorghe A., C. (2009). The northern slope of Fagaras Mts. The study of natural touristic potential and land pretability to the amenagement in the perspective of the development of mountain ecotourism (Versantul nordic al Masivului Făgăraș. Studiul potențialului turistic natural și al pretabilității terenului la amenajare în perspectiva dezvoltării turismului ecologic montan), PhD Thesis.

Hammitt, W., E. \& Cole, D.H.(1998). Wildland Recreation: Ecology and Management, 2nd ed. John Wiley, New York, 361 pp.

Hann, H., P. (1990). Cozia Gneiss (South Carpathians): Petrography, Structure, Genesis, D. S. Inst. Geol. Geofiz., vol. 74/5: 41-59, Bucarest.

Hose, T., A. (1995). Selling the story of Britain's stone. Environ. Interpret. 10 (2), 16-17.

Ilieş, Dorina, Camelia, Ilieş, A., Herman, G., Baias, Ş., Morar, C. (2011). Geoturist map of the Băile Felix- Băile 1 Mai - Betfia area (Bihor county, Romania), GeoJournal of Tourism and Geosites, Year IV no.2, vol. 8, 219-226.

Khoshtaria, T., K., \& Chachava, N., T. (2017). Prospects of ecotourism development in recreation areas of South Georgia, Annals of Agrarian Science, 15, 312-317.

Kucsicsa, G. (2013). Rodna Mountains National Park: human-environment relationship (Parcul Naţional Munţii Rodnei: relaţii om-mediu), Editura Universitară, București.

Leung, Y., \& Marion, J., L. (2000). Recreation impact and management in wilderness: a state-of-knowledge review. In: Cole, D.N., McCool, S.F., Borrie, W.T., and O’Loughlin, J. (comps.) Wilderness Science in a Time of Change Conference. Vol. 5. Wilderness Ecosystems, Threats and Management. Proceedings RMRS-P-15-VOL-5. U.S. Department of Agriculture, Forest Service, Rocky Mountain Research Station, Ogden, Utah, pp. 23-48.

Liddle, M. (1997). Recreation Ecology. Chapman \& Hall, London. 639 pp.

Liddle, M., J., \& Greig-Smith, P., J. (1975). A survey of tracks and paths in a sand dune ecosystem. Journal of Applied Ecology, 12, 893-930. 
Liddle, M., J., \& Kay, A., M. (1987). Resistance, survival and recovery of trampled corals on the Great Barrier Reef. Biological Conservation 42, 1-18.

Marion, J.L. \& Cole, D.N. (1996) Spatial and temporal variation in soil and vegetation impacts on campsites. Ecological Applications 6, 520-530.

Marion, J., L. \& Leung, Y. (2001). Trail resource impacts and an examination of alternative assessment techniques. Journal of Park and Recreation Administration, 19, 17-37.

Meinecke, E., P. (1928). The effect of excessive tourist travel on the California redwood parks. California Department of Natural Resources, Division of Parks, Sacramento. 20 pp.

Melelli, L., Vergari, F., Liucci, L., \& Del Monte, M. (2017). Geomorphodiversity index: Quantifying the diversity of landforms and physical landscape, Science of the Total Environment, 701-714.

Miccadei, E., Piacentini, T., Esposito, G., \& Santangelo, S. (2013). Activities and tools for Geotourism in the National Park of Abruzzo, Lazio and Molise (Attività e strumenti per il Geoturismo nel Parco Nazionale d'Abruzzo, Lazio e Molise), $5^{\circ}$ Congresso Nazionale di Geologia e Turismo "Viaggio nella Geologia d'Italia”, 6-7 Giugno 2013, Bologna.

Monti, P., \& Mackintosh, E., E. (1979). Effect of camping on surface soil properties in the boreal forest region of northwestern Ontario, Canada. Soil Science Society of America Journal, 43, 1024-1029.

Moțoc, M., Munteanu, S., Băloiu, V., Stănescu, P., \& Mihai, G. (1975). Soil erosion and methods of control (Eroziunea solului și metodele de combatere), Editura Ceres, București.

Necheș, I., M., \& Erdeli, G., (2015). Geolandscapes and geotourism: integrating nature and culture in the Bucegi Mountains of Romania. Lands. Res. 40 (4), 486-509.

Newsome, D., \& Dowling, R., K. (Eds.), (2010). Geotourism: The Tourism of Geology and Landscape. Goodfellow Publishers, Oxford.

Ovreiu, A., B., Bărsoianu, I., A., Nedelea, A., Comănescu, L., \& Nistor, C. (2018). Implementation of a new model on soil erosion. Case study - Văratica hydrographic basin (Cozia Mountains, Romania), Zeitschrift für Geomorphologie, DOI: https://doi.org/10.1127/zfg/2018/0486.

Piacentini, T., Castaldini, D., Coratza, P., Farabollini, P., \& Miccadei, E. (2011). Geotourism: some examples in northern-central Italy, GeoJournal of Tourism and Geosites, year IV no.2, vol. 8, 240-262.

Popescu N., C., \& Călin, D. (1987). Cozia Mountain (Munţii Coziei), „Our mountains” Collection (Colecţia „Munţii noştri”), Ed. Sport-turism, Bucureşti.

Punmanee, T. (2008). Incorporation of the cultural into understanding of ecotourism: Chaiyaphum province, Thailand al ATLAS annual conference 2008: Selling or Telling? Paradoxes in Tourism, Culture and Heritage, 2-4 July, 2008, Sallis Benney Theatre, University of Brighton, UK.

Stoffelen, A., \& Vanneste, D. (2015). An integrative geotourism approach: bridging conflicts in tourism landscape research. Tour. Geogr. 17 (4), 544-560.

Stueve, A., M., Cook, S., D., \& Drew, D. (2002). The Geotourism Study: Phase 1 Executive Summary. National Geographic Traveller, Travel Industry Association of America.

Yolal, M. (2012). Geotourism and geoparks: the case of Kizilcahamam-Çamlidere Geopark, GeoJournal of Tourism and Geosites, Year V no.2, vol. 10, 193-203.

Zabinski, C., A., \& Gannon, J., E. (1997). Effects of recreational impacts on soil microbial communities. Environmental Management 21, 233-238.

*** Google Maps - www.maps.google.com.

*** Government Decision no. 77/2003 on the establishment of measures for the prevention of mountain accidents and the organization to activities of rescue work in the mountains.

*** Government Decision no. 57/2007 approved with amendments and completions by Law no. 49/2011, as amended and supplemented.

*** Government Emergency Ordinance No. 57/2007.

*** Law No. 49/2011.

*** OSM (Open Street Map) - www.openstreetmap.org/

*** The MANAGEMENT PLAN OF NATIONAL COZIA PARK AND NATURA 200o SITES ROSCIO046 COZIA and ROSPAo025 COZIA-BUILA-VÂNTURARIŢA (www.mmediu.ro/app/webroot/uploads/files/201512-07_Plan_Management_PN__Cozia .pdf ).

*** The statute of the Cozia National Park and its Natura 2000 sites: ROSCIo046 Cozia and ROSPAo025 Cozia Buila-Vânturariţa. (www.mmediu.ro/app/webroot/uploads/files/2015-12-07_Regulamentul_Parcului_ Național_Cozia.pdf ).

***PN Cozia Management Plan, 2015.

Submitted:

21.12.2018
Revised:

19.02.2019
Accepted and published online 21.02.2019 